\title{
BiR DEVLET ADAMI OLARAK FÂiK ÂLi OZANSOY
}

\author{
Fâik Âli Ozansoy as a Statesman
}

\section{Sinan ÇiTçi*}

\begin{abstract}
ÖZ
Tanzimat'tan sonra gelişen Türk edebiyatı, yapısı itibarıly disiplinler arası çalışmalar yapmayı mecburi kılan bir alandır. Bu dönemdeki sanatkârların aynı zamanda devlet adamı olması, edebiyat ile yönetim bilimi arasındaki etkileşimin incelenmesini gerektirir. Bu bağlamda Fâik Âli Ozansoy, önemli bir figür olarak karşımıza çıkar. Fâik Âli Ozansoy, sanat hayatında olduğu gibi yöneticilik hayatında da ulviliklerin ve ütopik dünyaların peşindedir. Dil ve sanat konusunda muhafazakâr olduğu gibi kanunların tatbiki ve devletin bekası gibi konularda da muhafazakâr ve tavizsizdir. Hâlbuki Fâik Âli Bey'in yaşadı̆̆ dönem, böyle bir devlet adamı için oldukça acımasızdır. Fâik Âli Bey, yöneticilik hayatı boyunca, herhangi bir şahsa, zümreye ve partiye mensup olmak yerine kanunlara ve vicdanına bağlı olduğu için çoğu zaman yerel ve merkezî güçlerle karşı karşıya kalmıştır. Bu da -zamanla- Fâik Âli Bey'in edebî hayatında olduğu gibi özel hayatında da yalnızlaşmasına ve unutulmasına sebep olmuştur. Bu çalışma, ilkeli ve duygusal bir şairin, nasıl bir devlet adamı olduğunu göstermesi açısından önemlidir.
\end{abstract}

Anahtar Sözcükler: Şair, idealist, kaymakam, ittihat ve Terakki Cemiyeti, Ermeni.

\begin{abstract}
Turkish literature evolving following to the Tanzimat Edict, inherently necessitates inter-discipliner studies. As artists are also statesman in this period, this relation entails the examination of interaction between literature and administrative sciences. In this context, Faik Ali Ozansoy is an important figure. Faik Ali Ozansoy seeks for divine and utopic worlds in both his art and administrative life. He is conservative and uncompromising in language and art and also in enforcement of laws and survival of state. However, the period he lived in is highly cruel for such a statesman. During his administration, Faik Ali has always come across local and central authorities as he adhered to law and his conscience instead of any person, community or party. This situation, gradually, caused to be isolated and being forgotten for Faik Ali Bey's private life as in his literary life. This study is very important for showing how a principled and emotional poet could be what kind of a statesman.
\end{abstract}

Keywords: Poet, idealist, district governor, The Committee of Union and Progress, Armenian.

Yönetim şekillerine göre devlet yöneticilerine değişik adlar verilebilse de bu yazı bağlamında ele alınacak "devlet adamı" terimi, yasaların kendisine verdiği yürütme yetkisini kullanabilen, devlet başkanlığından en küçük mülki amirliğe kadar bütün idare mekanizmalarında çalışabilen kişidir. Bu tanıma göre askerî ve adli personeli, kalem efendilerini ve genel müdürleri, bu kavramın dışında tutmak gerekir.

\footnotetext{
*Yrd. Doç. Dr., İstanbul Üniversitesi Türkiyat Araştırmaları Enstitüsü, sinancitci@gmail.com
} 
Yönetim tarzına göre üç tip devlet adamı vardır. Birinci tip, romantik ve idealisttir. Bunların ilgi alanları genellikle tarih ve edebiyattır. Bu tip devlet adamları, ütopik dünyalar kurma azmiyle yola çıkarlar. Kanunları harfiyen uygulamayı, ilkelerden taviz vermemeyi prensip hâline getirirler; hatta onları kutsarlar. Muhafazakârdırlar, yeni durumlara kolay kolay ayak uyduramazlar; çünkü zor beğenirler. Gücün ve kontrolün kendi ellerinde olmasını isterler, çoğu zaman yerel ve haricî güçlerle uyumlu çalışamazlar. Problemleri düzeltme konusunda aceleci ve cesurdurlar; fakat problemin üstesinden gelemedikleri veya âmirlerince yalnız bırakıldıklarını anladıkları durumlarda küser ve geri çekilirler. İkinci tip devlet adamları realist ve pragmatisttirler. Bunların ilgi alanları ise genellikle psikoloji, sosyoloji ve ekonomidir. Idealist kanunlarla dünyanın cennet olmayacağının farkında oldukları için kanunları kutsamaz ve onların tatbikinde esnek davranırlar. İşe realiteleri kabulle başladıkları için gittikleri yere çabuk adapte olur ve her seviyeden insanla kaynaşırlar. Problemler karşısında aceleci değil, tedricî hareket ederler; pes etmez, alternatif çözümler ararlar. Üçüncü tip devlet adamı ise bu iki davranış tarzını birleştirip kâh birini kâh diğerini kullanır. Başarılı devlet adamları genellikle bu son sınıfın içinden çıksa da bu tipin örneklerini göstermek oldukça zordur.

Yeni Türk edebiyatı, sosyal ve politik hadiselerin içinde doğup geliştiği için hemen her edebî devrenin ve muhitin mensupları arasında pek çok devlet adamı vardır. Bu tür şahsiyetlerin; sanatkâr ve devlet adamı yönlerinin birbirleriyle olan ilişkisinin ve etkileşiminin tespitinin, sosyal bilimlere katkı sağlayacağı şüphesizdir. Servet-i Fünûn ve Fecr-i Âti edebî hareketlerinde yer almış olan Fâik Âli Ozansoy da şairliğinin yanı sıra önemli zamanlarda, kritik noktalarda görev yapmış bir devlet adamıdır. Fâik Âli, bugüne kadar sanatkâr ve şair kimliğiyle ciddi anlamda ele alınıp incelenmediği gibi devlet adamlığıyla da inceleme konusu yapılmamıştır. Bu çalışmanın konusu, dostlarının ve yakınlarının hatıralarından ve arşiv belgelerinden hareketle Fâik Âli'nin resmî hâl tercümesiyle ilgili edebiyat tarihlerinde tekrarlanan hükümleri değerlendirmeye tabi tutmak ve yukarıdaki tasnifi esas alarak Fâik Âli'nin nasıl bir devlet adamı olduğunu ortaya çıkarmaktır.

\section{1) Doğumu ve Eğitim Hayatı}

Fâik Âli Bey'in babası Mehmed Saîd Paşa (1832-1892), Diyarbakırlı köklü bir aileye mensuptur.' Mirâtüll-iber ve Mizânüll-Edeb müellifi Mehmed Saîd Paşa âlim ve şairliğinin yanı sıra önemli bir devlet adamıdır. ${ }^{2}$ Saîd Paşa'nın babası Süleyman Nazif Efendi (1786-1832) de manzum ve mensur eserleri olan bir kalem efendisidir. Onun babası ibrahim Cehdî Efendi (1768-1806) ise daha ziyade âlim ve şair olmasıyla bilinir. Fâik Âli'nin baba tarafindan soyu Hz. Hüseyin'e, anne tarafından da “Akkoyunlu

\footnotetext{
' Sevim Karabela, Fâik Âlî Ozansoy - Hayatı - Eserleri ve Sanatı, Gazi Üniversitesi Sosyal Bilimler Enstitüsü, Basılmamış Yüksek Lisans Tezi, Ankara 1997, s. 3-4.

${ }^{2}$ Mehmed Saîd Paşa'nın diğer eseleri; Divançe-i Eşâr, Türkçe Hülasa-i Mantık, Miráat-ı Sıhhat, Nuhbet'ül-Emsâl, Tabsırat'ul-insan'dır. Mahmut Soysüllü, Süleyman Nazif Makaleleri (1909'a Kadar), Basılmamış Mezuniyet Tezi, ìstanbul Üniversitesi, Edebiyat Fakültesi, Türkoloji Bölümü 1969-1970. Türkiyat Araştırmaları Enstitüsü, No: 949.
} 
Devleti'nin en kuvvetli istinatgâhı olan 'Hindî' adlı bir Türk aşiretinin reisi”ne dayanır.' Ali Emirî Efendi ile İsmail Hâmi Danişmend, Fâik Âli'nin mensubu olduğu ailenin ana tarafindan Artukoğullarına dayandığını söyler. ${ }^{4}$ Fâik Âli'nin ağabeyi Süleyman Nazif de şair ve nâsirliğinin yanı sıra değişik vilayetlerde valilikler yapmış bir devlet adamıdır. Buna göre Fâik Âli'nin ilmiyye ve kalemiyyeye mensup bir ailenin ferdi olduğu söylenebilir.

Fâik Âli, Diyarbakırlı Saîd Paşa ile soyu Şair Hâmî Efendi'ye dayanan Ayşe Hanım'ın küçük oğludur. Kaynaklarda doğum tarihiyle ilgili farklı rivayetler olmasına ${ }^{5}$ rağmen, kuvvetli ihtimalle 26 Ocak 1876 (29 Zilhicce 1292) tarihinde, ${ }^{6}$ Diyarbakır'da "babası Saîd Paşa'nın ismiyle maruf sokağın altı nolu evinde" doğar. ${ }^{7}$ Devlet, millet ve medeniyet meselelerinin konuşulduğu bir muhitte büyüyen Fâik Âli; ilmî, edebî ve idari anlamda ilk terbiyesini aile ortamında alır. Babası ve ağabeyinin tesiriyle ilk olarak Namık Kemal'i ve zatına hayranlığı hayatının sonuna kadar devam edecek olan Abdülhak Hâmid'i tanır. Namık Kemal'in tarihî biyografileri ile Abdülhak Hâmid'in tarihî tiyatrolarında idealize ettiği kahramanları ve devlet adamlarını okuyarak büyüyen Fâik Âli'nin, kendisini devlet adamlığına götürecek bir tahsil yoluna girmesi çok tabiidir. Faik Âli, ilköğrenimine Diyarbakır'da sıbyan mektebinde başlar. Temel ilimleri öğrendikten sonra Diyarbakır'da askerî ${ }^{8}$ rüşdiyeye girer. 6 Mayıs 1888 tarihinde rüşdiyeden iyi dereceyle mezun olur ve idadiye başlar. 30 Kasım 1892 tarihinde, babası Mehmed Said Paşa, Mardin mutasarrıfı iken orada vefat eder. ${ }^{9}$ Yaşının küçüklügü istanbul'da tahsiline mâni olduğu için ${ }^{10}$ Fâik Âli, bir yıl daha Diyarbakır'da okur; hicrî 13ı' de (1893/1894), on dokuz yaşında

\footnotetext{
${ }^{3}$ Fâik Âli ve ağabeyi Süleyman Nazif in dedeleri ve soyu hakkında ayrıntılı bilgi için $b k$. Muhammet Gür, Makale ve Mektuplarına Göre Süleyman Nazif, Marmara Üniversitesi Türkiyat Araştırmaları Enstitüsü, Basılmamış Doktora Tezi, ìstanbul 1992, s. 4-10.

${ }^{4}$ Semih Mümtaz S., “Evvel Zaman iç̧inde: Râbia Hatun Davası - Üstat Fâik Âli'nin Râbia Hatun'a ve Şiirlerine Dair Mühim Sözleri”, Akşam Gazetesi, 16 Ağustos 1948, s. 4.

${ }^{5}$ Hıfzı Tevfik 1873 yılında, İsmail Habip, Behçet Necatigil ve Abdülhak Şinasi Hisar 1875 yılında, Ali Canip, Şevket Beysanoğlu, Atilla Özkırımlı, Kenan Akyüz, İsmail Parlatır, Mücellidoğlu Ali Çankaya, İbnülemin Mahmud Kemal İnal ve Raşit Koç 1876 yılında, Murat Uraz da 1878 yılında doğduğunu söyler.

${ }^{6}$ Dâhiliye Nezareti Sicill-i Ahval Defterinde ve Babıâli Memurîn-i Mülkiyye Komisyonu'nun hazırladığı terceme-i hâllerde, Fâik Âli Bey'in hicri 1292 yılında doğduğu ifade edilir. Torunu Ayşe Erkmenoğlu'nda bulunan hüviyet cüzdanının doğum tarihi bölümünde de "292" senesi kayıtlıdır. T.C. Başbakanlık Osmanlı Arşivi'ndeki 29 Zilhicce 1292 tarihli belgede de Faik Âli Bey'in 1292 yılında Diyarbakır'da doğduğu ifade edilir. Buna göre Fâik Âli, ya 26 Ocak 1876 (29 Zilhicce 1292) tarihinde veya bu tarihten biraz önce doğar. BOA, DH.SAiD, Sıra No: 0112, sayfa: 413-414.; BOA, i.DH, 1433 / 21. (1. Belge); BOA, Y.A.RES, 151 / 48. 3 Numaralı belge.; BOA, DH.SAIDd..., 112 / 413.

${ }^{7}$ Muzaffer Budak Seyfettinoğlu, "Fâik Âli Ozansoy: Unutulan Şair". Sanat Dünyası, Nr: 216, Aralık 1965, s. 3.

${ }^{8}$ i smail Parlatır, “Faik Âli Ozansoy”. TDV islam Ansiklopedisi, C 12, ìstanbul 1995, s. 100.

${ }^{9}$ Muhammet Gür, age., s. 9.

${ }^{10}$ Hamdullah Suphi Tanrı̈ver, "Musahabe-i Edebiyye: Fâik Âli, Fâni Teselliler", Musavver Muhit, 22 Kanunusani 1324, C1, s. 197.
} 
Istanbul'a gelir" ve Mekteb-i Mülkiye'nin idadî kısmına yatılı olarak devam eder.'2 11 Temmuz 1898'de pekiyi derece ile mezun olur. ${ }^{13}$ Daha sonra Mekteb-i Mülkiyye'nin yüksek kısmına başlar. Daha Diyarbakır'dayken şiirler yazıp göndermeye başlayan ${ }^{14}$ Fâik Âli, İstanbul'da aradığı edebî muhiti bulur ve devrin önemli şair ve yazarlarıyla irtibata geçer. Mekteb-i Mülkiyye'nin idadi ve âli kısımlarında "edebiyat" ve "kitabet-i resmiyye" dersleri veren, ${ }^{15}$ hocası Menemenlizâde Mehmed Tahir, ${ }^{16}$ Recaizâde Ekrem ve ağabeyi Süleyman Nazifin aracılığıyla Servet-i Fünûn edebî topluluğuna girer. Servet-i Fünûncular, zamanın politikası icabı şiirlerinde sosyal ve politik meselelerden bahsetmeseler de bir şekilde sosyal ve politik hadiselerin içerisindedirler. Temasta bulundukları sefaret mensupları, Fransız ve Amerikan okullarının hocaları, levantenler, azınlık aydınları, Mısır ve Avrupa'daki Jön Türkler ile onların memlekete soktukları gazete, dergi ve kitaplar, Servet-i Fünûncuların o günkü Türk toplumuna ve değerlerine farklı açılardan bakmalarına sebep olur. Servet-i Fünûn mecmuası etrafinda toplanan şair ve yazarlarla sıkça görülmesi, bazı şiirlerinin bu dergide yayımlanması, okuldaki bazı hadiselere karışması ${ }^{17}$ ve "Avrupa'daki Jön Türklerle muhaberede bulunduğu şüphesi”nden hareketle Fâik Âli, 16 Eylül 1899 tarihinde gözaltına alınır ve otuz altı gün tutuklu kalır. ${ }^{18}$ Midhat Cemal'e yazdığı mektupta kısaca değindiği bu hâdiseden ağabeyi Süleyman Nazif ve Ahmed Celaleddin Paşa'nın saray nezdindeki gayretleri sayesinde kurtulduğunu söyler:

Kardeşimin Fikret'e yazdı̆̆ı 25 Eylül 1315 tarihli mektupta bahsettiği, benim geçirdiğim değil, o günlerde henüz geçirmekte olduğum felaket. Avrupa'daki jön Türklerle muhaberede bulunduğum şüphesinden dolayı Zaptiye Kapısı'ndaki mevkûfiyyetimdir. Bu hâdise arkadaşlarımdan biri,

\footnotetext{
" ibnülemin Mahmud Kemal İnal, "Faik Âli Bey", Son Asır Türk Şairleri, Cüz: ll. İstanbul: Millî Eğitim Basımevi, 1969, s. 360.; M. Fatih Andı, "Fâik Âli Ozansoy'un Servet-i Fünûn Edebiyatı ve Tevfik Fikret'e Dair Midhat Cemal Kuntay'a Yazdığı Mektuplar", Edebiyat Araştırmaları - I. istanbul: Kitabevi, 2000, s. 177.

${ }^{12}$ M. Fatih And, age., s. 178.

${ }^{13}$ BOA, DH.SAID, Sira No: 0112, s. 413-414.

${ }^{14}$ Fâik Âli'nin ilk yayımlanan şiiri, Diyarbakır'dan gönderdiği, Maarif dergisinde çıkan "Muhabbet" adlı şiiridir. Muzaffer Uyguner, "Ölümünün Yirminci Yılında Fâik Âli Ozansoy". Mülkiyeliler Birliği Dergisi, C 3, 21, s. 25.

${ }^{15}$ Necat Birinci, Menemenlizâde Mehmed Tahir. Ankara: Kültür ve Turizm Bakanlığı Yayınları, 1988, s. 6.

${ }^{16}$ Menemenlizâde Mehmed Tahir'in Tevfik Fikret'le aralarının bozulması ve ayrılması daha sonradır. M. Fatih Andı, age., s. 184.

${ }^{17}$ Kenan Akyüz, Batı Tesirinde Türk Şiiri Antolojisi. Beşinci Baskı, İstanbul: İnkılâp Kitabevi, 1995, 414.; Şevket Beysanoğlu, Diyarbakırlı Fikir ve Sanat Adamları, C 2, İstanbul: Işıl Matbaası, 1960, 346.

${ }^{18}$ Ismail Parlatır, gözaltına alındığı için bir yıl kadar okula gidemediğini, Kenan Akyüz ise 1900 yılında tevkif edilip bir ay kadar hapsedildiğini söyler. İsmail Parlatır, age., s. 100. ; Kenan Akyüz, age., s. 414. Celal Sâhir de Fâik Âli ile tanışmasını anlatırken bu hadiseye temas eder: "Servet-i Fünûn'a da bir iki yazı yolladım. Neşrolunmadı. Sonra o esnada Fâik Âli Bey'le tanışıım. O, hapsolmuştu. Hapiste iken yazdığ yazıları Servet-i Fünûn'da Zâhir imzası ile neşretmişti." Mecdi Sadrettin, Sevdiklerimiz - 1. İstanbul: Milliyet Matbaası, 1929, s. 22.
} 
Istanbul'a geldiğim gün tanışıp çok seviştiğimiz rahmetli Cemal'di. Yusuf izzeddin Efendi merhûmun teşrifatçısı Cemal. Bu meselede tevkîf edilmiş olanlar muhtelif meslek ve meşrebde kırk kadar zavallı imiş. On altı Eylül'de başlayıp tam otuz altı gün sürmüss olan bu mevkûfiyyetim, ŞSark'in mutantan sultan-ı zekâsı' olduğu kadar Türk'ün en ziyade medenî celâdete sahip evladlarından da biri olan, her manasıyla büyük kardeşimin Yıldız'a yağdırdı̆̆ı yıldırımdan telgraflar ve çok haksız yere 'serhafiye' denilen, cidden vatanperver ve hürriyetperest Ahmed Celaleddin Paşa merhûmun padişah nezdindeki teşebbüsleri sayesinde nihayet bulmuş ve bu sayede kırk kadar masum da meçhul akıbetlerden kurtulmuştu. Çünkü padişah, mesele kapatılsın diye irade etmiş. Bu maceranın pek ziyade mudhik, oldukça da fecî safahâtı var. Bunlar yazılsa alaka çekecek bir roman olur. Bir Çarşamba günü, ikindiye doğru iki hafiye mektebe gelip beni oradan almış ve Bâb-ı Zaptiye'ye götürmüştü. Otuz altı gün sonra, yine bir Çarşamba günü, yine ikindi üstü serbest bırakılmıştım. O günün ferdası, akşam mektepten âzâd olup çıkınca, Bâbıâli Caddesi'nin Divanyolu'na bakan bir noktasında karşılaştığımız Hüseyin Kâzım merhumun, kollarını bütün vüs'atiyle açarak 'Ah, sen tasfiye-i vicdan ettin, biz kaldık.' Nidâ-yı telehhüf-nümâsılyla boynuma sarılıp ağladığını ömrüm oldukça unutamam. Serde Edebiyat-ı Cedîde şairliği payesi olduğundan, benim tevkîfim birçok muhitlerde heyecan uyandırmıştı. ${ }^{19}$

Gerek bugün için tam vuzuha kavuşmamış olan siyasi faaliyetlerinden, gerek Edebiyat-ı Cedîde muhitiyle fazla temasından dolayı okuldan soğur ve devamsızlığı artar. Fâik Âli, Mekteb-i Mülkiye'nin son sınıfindayken, yıllık eğitim öğretim süresinin ancak dörtte biri kadar okula devam ettiği için sene sonu imtihanına kabul edilmez. Bunun üzerine kendisiyle aynı durumda olan arkadaşları Mehmed Sâdi ve Burhaneddin Efendilerle birlikte imtihana kabul edilmek için Mekteb-i Mülkiye Müdüriyeti'ne dilekçe verir. Mekteb-i Mülkiye de durumu, 8 Haziran 1901 tarihinde, Maarif Nezareti Meclis-i Kebirine havale eder. II Haziran'da toplanan Maarif Nezareti Meclis-i Kebiri ise mevcut kanunları gerekçe göstererek, bu öğrencilerin imtihana kabul edilmemelerine karar verir. Fakat -her nasılsa- bu arada saray, meseleye müdahil olur. Bir gün sonra, Yıldız Saray-ı Hümayunu Başkitabet Dairesi'nden gelen yazıda Fâik Âli ile arkadaşlarının adaletsizlikle rencide edilmemeleri istenir. Bunun üzerine Maarif Nezaret-i Umumiyye Meclis-i Kebîri 15 Haziran 1901 tarihli yazısında bu öğrencilerin imtihana alınmalarını ister. ${ }^{20}$ ìsmail Parlatır, bu karar değişikliğine de ağabeyi Süleyman Nazifin araya girmesinin sebep olduğunu söyler. ${ }^{21}$ Dağdağalı bir tahsil hayatının sonunda Fâik Âli, nihayet 13 Temmuz 1901 tarihinde, Mekteb-i Mülkiyye'den pekiyi dereceyle mezun olur. ${ }^{22}$ Sicill-i Ahval

\footnotetext{
${ }^{19}$ M. Fatih And, age., s. 180-181.

${ }^{20}$ BOA, MF.MKT, 565 / 4, (1., 2., 3. ve 4. belgeler)

${ }^{21}$ ismail Parlatır, age., s. 100.

${ }^{22}$ BOA, DH.SAiD, Sıra No: 0112, sayfa: 413-414.; Mücellidoğlu da “Temmuz 1901'de" mezun olduğunu söyler. Mücellidoğlu Ali Çankaya, Yeni Mülkiye Tarihi ve Mülkiyeliler (I860-1908 Atik Mekteb-i Fünûn-ı Mülkiyye - Mekteb-i Mülkiyye-i Şahane Mezunları), C III, Ankara: Mars Matbaası, 1968-1969, s. 880.; ibnülemin ise Rumî 1317 (1901/1902) tarihinde Mekteb-i Mülkiye'den mezun olduğunu söyler. ibnülemin, age., s. 360.
} 
Defteri'nde Fâik Âli'nin Arapça, Farsça, Türkçe ve Fransızca konuşup yazabildiği ve Kürtçe'yi de anladığı ifade edilir. ${ }^{23}$ Bununla birlikte Fâik Âli, Midhat Cemal'e yazdığı mektupta Arapça'yı, Kur'ân'ı anlayacak kadar değil, Türkçe'ye lazım olduğu kadar bildiğini söyler. ${ }^{24}$

\section{2) Devlet Adamlığ}

\section{a) ilk Adım: Bursa'da Maiyet Memurluğu}

5 Şubat 1902'de, ağabeyi Süleyman Nazif in vilayet mektupçusu olarak görev yaptığ Bursa'ya maiyet memuru olarak atanan ${ }^{25}$ Fâik Âli, 15 Şubat'ta Bursa'da göreve başlar. ${ }^{26} 3$ Mayıs 1902'de Mihaliç kazası tahakkuk memurluğuna, 1 Ağustos 1904'te de Mudanya kazası âşâr-ı ihale memurluğuna tayin edilir. Burada hazinenin menfaatine olacak şekilde görev yapar. ${ }^{27}$ Aynı yıl Ayvalık (27 Ağustos 1904 - 8 Eylül 1904) ve Gönen kazaları kaymakamlı̆̆ına (16 Eylül 1904 - 22 Kasım 1904) vekâlet eder. ${ }^{28}$ Fâik Âli o yıllarda Balya kaymakamlığına da vekâlet eder. ${ }^{29}$ Erdek kaymakamının vefatı üzerine 1904 Aralığında Erdek kazası kaymakamlığına da vekâlet eder. ${ }^{30}$ Bu görevdeyken, asil kaymakamlık için şart olan üç seneyi doldurur. ${ }^{31}$

\section{b) ilk Mülkî Âmirlik: Sındırgı Kaymakamlığı}

Sındırgı kazası kaymakamı Ragıb Bey'in eğlenceye düşkünlüğü ve devlet işlerini ihmalden dolayı azledilmesi üzerine, daha önceki güzel hizmetlerinden dolayı Fâik Âli, 9 Mart 1905 tarihinde Sındırgı kazasına kaymakam olur. ${ }^{32}$ Ağabeyi Süleyman Nazif, Bursa'da vilayet mektupçusu olduğu için muhtemel şikâyet ve dedikodulara meydan vermemek için Iç̧işleri Bakanlı̆̆ı Mülkiye Memurları Komisyonu, ilk bașta Fâik Âli'nin Sındırgı'ya atanmasını tereddütle karşılar. Uzun müzakereler sonunda Sındırgı'nın Karesi sancağına bağlı olması, Fâik Âli'nin o güne kadarki görevlerinde yüksek başarı göstermesi, Mekteb-i Mülkiyye mezunu olması ve ihtiyaç hissedilmesi tercih edilmesine sebep olur. Fâik Âli, 23 Nisan 1905 tarihinde göreve başlar. ${ }^{33}$ Fâik Âli, Sındırgı kaymakamlığı sırasında Ayvalık (28 Mayıs 1905 - 4 Ağustos 1905), Balya (2 Eylül 1905 -

\footnotetext{
${ }^{23}$ BOA, DH.SAID, Sira No: 0112, s. 413-414.

${ }^{24} \mathrm{M}$. Fatih And1, age., s. 184-185.

${ }^{25}$ BOA, DH.MKT, 2584 / 79. ibnülemin de tayin tarihinin Şubat 1317 olduğunu söyler. ibnülemin, age., s. 360 .

${ }^{26}$ BOA, DH.SAID, Sira No: 0112, s. 413-414.

${ }^{27}$ BOA, DH.SAID, Sira No: 0112, s. 413-414.

${ }^{28}$ BOA, DH.SAID, Sıra No: 0112, s. 413-414.

${ }^{29}$ Mücellidoğlu Ali Çankaya, age., s. 881.

${ }^{30}$ BOA, BEO, 2523 / 189169 (2. Belge); BOA, DH.MKT, 917 / 90.

${ }^{31}$ Mücellidoğlu Ali Çankaya, age., s. 881.

${ }^{32}$ BOA, Tasnif No: i.DH, 1433 / 21.; BOA, DH.MKT., 936 / 86; BOA, BEO, 2560 / 191986.

${ }^{33}$ BOA, DH.SAID, Sira No: 0112, s. 413-414.
} 
11 Ocak 1906) ve Burhaniye ${ }^{34}$ kazalarının (18 Aralık 1905 - 8 Nisan 1906) kaymakamlık vekâletlerini de yürütür. ${ }^{35}$

\section{c) Burhaniye Kaymakamlı̆̆}

Celal Bey'in azledilmesi üzerine 9 Nisan 1906 tarihinde, Burhaniye'ye atanan ${ }^{36}$ Fâik Âli, 1906 Temmuzunda göreve başlar. ${ }^{37}$ Fakat Burhaniye'de mahallî memurlarla ve eşraf ile anlaşamaz. iç̧işleri Bakanlığına gönderilen dilekçede Fâik Âli'nin kendi düşüncelerine ters düşen memurları tehdit ettiği, bazılarını azlettiği, müftünün, mal müdürünün ve azadan Ahmed ve Vangel Efendilerin idare meclisine gelmelerini engellediği, Ayvalık'tan gelen doktoru geri gönderdiği, eczane açmak isteyen diplomalı eczacılara izin vermediği, süresi dolan Belediye Başkanı'nı seçime lüzum görmeden görevinde tuttuğu, mal müdürünü palamut müdüriyetine atayarak oradan kendisine çıkar sağladığı, birtakım iftiralarla adliye personelini çalıştırmadı̆̆ı ifade edilir. Babıâli Daire-i Umûr-ı Dahiliye Memurîn Kalemi'nden Bursa Valiliği'ne giden 23 Ekim 1907 tarihli yazıda bu şikâyetlerin oldukça önemli olduğu ve acilen araştırılması gerektiği ifade edilir. ${ }^{38}$ Fâik Âli'nin bu iddialara nasıl cevap verdiğini bilemiyoruz.

\section{d) Pazarköy Kaymakamlığı}

O sırada Pazarköy kaymakamı ibrahim Fevzi Efendi, okuyup yazmadaki iktidarsızlığı, devlet işlerindeki vukufsuzluğu, muhacirlerin yerleştirilmesi konusundaki baştan savmacılığı ve idaredeki aczinden dolayı azledilir. Bunun üzerine Fâik Âli, 30 Kasım 1907 tarihinde Pazarköy kaymakamlığına atanır ${ }^{39} 1908$ Nisan'ında da göreve başlar. ${ }^{40}$ Üç ay sonra 11. Meşrutiyet ilan edilir. Terfi müddeti dolmadı̆̆ı hâlde ${ }^{41} 2$ Ağustos 1908'de ikinci sınıf kaymakamlığa terfi eder $^{42}$ ve 2 Ağustos 1908'den 2 Eylül 1908'e kadar Mudanya kazası kaymakamlığına da vekâlet eder. ${ }^{43}$ Bu arada tedavi görmek için ístanbul'a gider ve bir aydan fazla kalır. ${ }^{44}$ Dönüşte görev yeri değiştirilir.

\footnotetext{
${ }^{34}$ BOA, DH.MKT, 1043 / 21. (1. Belge)

${ }^{35}$ BOA, DH.SAiD, Sıra No: 0ı12, s. 413-414.; Mücellidoğlu Ali Çankaya, age., s. 881.

${ }^{36}$ BOA, DH.SAID, Sıra No: 0112, s. 413-414; Başka bir belgede 13 Nisan 1906 (18 Safer 1324) tarihinden bahsedilir. BOA, BEO, 2804 / 210254.

${ }^{37}$ Fâik Âli Bey, Temmuz 1906'da Burhaniye Kaymakamlığına nakledildiğini söylüyor. Bu ifadelerle muhtemelen tayin tarihini değil, göreve başlama tarihini kastediyor. Mücellidoğlu Ali Çankaya, age., s. 881.

${ }^{38}$ BOA, DH.MKT., $1208 / 45$.

${ }^{39}$ BOA, Y..A...RES., 151 / 48. Sicill-i Ahval Defterinde ise Fâik Âli Bey'in Burhaniye kaymakamlı̆̆ görevinin 29 Mart 1908 (16 Mart 324) tarihinde sonlandığı ifade ediliyor. BOA, DH.SAiD, Sıra No: 0112, s. 413-414.; BOA, DH.MKT., 1213 / 85.

${ }^{40}$ Fâik Âli Bey, Nisan 1908'de Pazarköy Kaymakamlığı'na nakledildiğini söylüyor. Bu ifadelerle de muhtemelen tayin tarihini değil, göreve başlama tarihini kastediyor. Mücellidoğlu Ali Çankaya, age., s. 881.

${ }^{41}$ Mücellidoğlu Ali Çankaya, age., s. 881.

${ }^{42}$ BOA, DH.MKT., 1274 / 18.

${ }^{43}$ BOA, DH.SAID, Sira No: 0112, s. 413-414.

${ }^{44}$ BOA, DH.MKT., 1274 / 74.; BOA, DH.MKT., 732 / 24.
} 


\section{e) Mudanya Mutasarmfliğı}

Salih Bey'in istifası ve Mudanyalıların isteği üzerine ${ }^{45}$ Fâik Âli, 18 Eylül 1908'de Mudanya mutasarrıflı̆ına atanır. ${ }^{46}$ Fakat Mudanya'ya alışamadığı için görev yerinin değiştirilmesini ister. ${ }^{47} 28$ Temmuz 1909 'da Fâik Âli'nin Mudanya mutasarrıflı̆̆ fiilen sona erer. Vilayet meclis-i idaresinden ve mahallî meclis-i idarelerden Dâhiliye Nezaretine giden mazbatalarda Fâik Âli'nin görevini en iyi şekilde yaptı̆̆ı ve ahlaki faziletleriyle halkın hoşnutluğunu kazandığı ifade edilir. ${ }^{48} \mathrm{Bu}$ arada, Gebze kaymakamı Mehmed Tahir Efendi'nin emekliliğini istemesi üzerine, 1 Temmuz 1909 tarihinde Fâik Âli, Gebze Kaymakamlı̆̆'na atanır. ${ }^{49}$ Fakat Mehmed Tahir Efendi'nin emeklilik işlemleri uzadığ ${ }^{50}$ için Fâik Âli, Gebze'de göreve başlayamaz. 1909 Eylül'ünde başlayan Tensikât'la birlikte Fâik Âli, üç derece terfi edince de Gebze'ye gitmeden görev yeri değiştirilir. ${ }^{51}$

\section{f) Midilli Mutasarrnflı̆̆}

Fâik Âli, 8 Eylül 1909'da Midilli mutasarrıflı̆ına atanır..$^{52}$ Süleyman Nazif, kardeşinin çok genç yaşta, üç derece terfi ettirilerek ${ }^{53}$ Midilli'ye atanmasını, zamanın iç̧işleri Bakanı Talat Bey'in "kendisine karşı bir cemilesi" olarak anlatır. ${ }^{54}$ Fâik Âli'nin Midilli'deki görevinin ilk iki yılı sükûnet içinde geçer. İki yıldır izin kullanmayan Fâik Âli, 20 Mayıs 1911'de verdiği dilekçede hem istirahat hem de Avrupa'ya seyahat amacıyla iki aylık izin ister ${ }^{55}$ fakat İtalya ile müstakbel bir muharebenin emareleri göründüğünden ${ }^{56}$ izin verilmez. Zaten kısa bir zaman sonra (29 Eylül 1911) İngiltere ve Fransa hükümetlerinin desteğini alan italya, Osmanlı Devleti'ne savaş açar. 4 Mayıs 1912'de Rodos'u, ilerleyen

\footnotetext{
${ }^{45}$ Mücellidoğlu Ali Çankaya, age., s. 881.

${ }^{46}$ BOA, DH.MKT., I297 / 41; BOA, DH.MKT., 2657 / 7.; BOA, i..DH.. 1469 / 93; BOA, BEO, 3402 / 255102. Sicill-i Ahval Defterinde Mudanya'ya tayininin 2l Eylül 1908 (24 Şaban 1326) tarihinde yapıldığı yazıyor. BOA, DH.SAID, Sıra No: 0112, s. 413-414.

${ }^{47}$ BOA, DH.MKT., 2856 / 31.

${ }^{48}$ BOA, DH.SAID, Sira No: 0112, s. 413-414.

${ }^{49}$ BOA, DH.MKT., 2882 / 91; BOA, BEO, 3590 / 269227.; BOA, DH.SAID, Sira No: 0112, s. 413414.

${ }^{50}$ BOA, DH.MKT., 2882 / 91; BOA, DH.MKT., 2867 / 88.

${ }^{51}$ Mücellidoğlu Ali Çankaya, age., s. 881.

${ }^{52}$ BOA, DH.SAID, Sıra No: 0112, s. 413-414. Başka bir evrakta Midili'ye 20 Eylül 1909 (5 Ramazan 1327) tarihinde tayin olduğu söyleniyor. BOA, DH.Mui., 12/-2 / 5.; BOA, DH.MUi, 12-2 / 5. Fâik Âli Bey ise "16 Eylül 1909'da Midilli Sancağı Mutasarrıflğğna tayinim tensîb ve icrâ edildi." diyor. Mücellidoğlu Ali Çankaya, age., $s .881$.

${ }^{53}$ Muzaffer Uyguner, age., s. 24.

${ }^{54}$ Nahid Sırrı Örik, “Haftada Bir: San’at Hayatından Akisler”, Milliyet Gazetesi, 09.10.1950, s. 2. ${ }^{55}$ BOA, ŞD, 39 / 34. (6. Belge)

${ }^{56}$ Fâik Âli Bey, Kütahya mutasarrıfı olduğu döneme kadar, tam maaşlı yıllık iznini kullanamaz. Nitekim Kütahya ve Üsküdar mutasarrıflı̆̆ı döneminde yazdığı dilekçelerde, İtalya Muharebesi dolayısıyla kullanamadı̆̆ı iki aylık izin hakkını ve daha sonraki yıllarda kullanamadı̆̆ izin haklarını zikrederek 3 aylık izin talebinde bulunur. Dâhiliye Nezareti Hukuk Müşavirliğinin verdiği cevaplardan anlaşılı̆̆ına göre, memurların yıllık izinleri, mücbir bir sebep altında en fazla üç yıl tehir edilebilir. BOA, ŞD, 39 / 34. 3. ve 5. Belgeler.
} 
günlerde On iki Ada'yı işgal eder. 12 Temmuz'da Italyan savaş gemileri Çanakkale Boğazı́na girer. Bu sırada kardeşinin durumundan endişe eden Süleyman Nazif, 6 Mayıs'ta İstanbul'dan Midilli'ye gider; on yedi gün kalır. İtalyanların adayı işgal ihtimalleri zayıflayınca, İstanbul'a döner. ${ }^{57} 8$ Ekim'de Karadağ da savaş ilan edince, Osmanlı Devleti, İtalya ile Uşi Antlaşması́nı (15 Ekim 1912) imzalamak zorunda kalır.

Fâik Âli'nin ìtalyan Harbi'nden önce karşılaştığı en büyük idari problem, belediyelerce konulan nakdi cezaların toplanamamasıdır. Cezaların tahsili konusunda hükümet, İstanbul'da belediye başkanını, taşrada ise en büyük mülki âmiri yetkili kılmıştır. Bununla birlikte Midilli Müdde-i Umumî Muavinliği, cezaların tahsiliyle ilgili adli işlemlerin yapılması konusunda ağır hareket etmektedir. Fâik Âli, 18 Mayıs 1912 tarihinde çektiği telgrafla durumu İçişleri Bakanlığına, ${ }^{58}$ içişleri de Adalet Bakanlığına bildirir. Adalet Bakanlığı, 9 Haziran 1912 tarihli cevabi yazısında, mülki âmirin yetkili kılındığıyla ilgili Midilli Müdde-i Umumî Muavinliğinin bilgilendirildiğini ifade eder. ${ }^{59}$ Yazışmalardan anlaşıldığına göre Fâik Âli, baş gösteren irtibatsızlı̆ga ve keşmekeşliğe son vermek ve zayıflayan devlet otoritesini yeniden tesis etmek istemektedir.

Fâik Âli'nin savaş başladıktan sonra karşılaştığı en büyük problem ise askerî yetkililere söz dinletememesidir. Fâik Âli, kanuna ve nizama uymayan icraatlarından dolayı Pilmar Jandarma takım kumandanı Hasan Efendi'nin muhakeme altına alınması için tabur kumandanına emirler verdiği hâlde, askerî yetkililerin mülki âmir olarak kendisini dinlememesi üzerine 20 Haziran 1912 tarihinde, İçişleri Bakanlığına görevden çekildiğini bildirir. ${ }^{60}$ Görevden çekilişinin "müşkil bir zemin ve zamanda vazifeden kaçmak için bahane aramak" şeklinde telakki edilmesi üzerine, üç gün sonra iç̧işleri Bakanlığına gönderdiği yazıda maksadının kanunları yerine getirmek ve bakanlığın haysiyetini korumak olduğunu, bu amaçla görevine başlayacağını fakat aksi bir durumla karşılaşırsa görevini ve memuriyetini terk etmeyi namus vecibesi sayacağını ifade eder. ${ }^{6}$ Iç̧işleri Bakanlığı da jandarma ve zabıta meselesinin acilen, kanuna uygun şekilde düzeltilmesini ister. ${ }^{62}$ l. Balkan Harbi'nin başlamasından kısa bir süre önce, Eylül 1912'de Fâik Âli, Midilli'den ayrılır. ${ }^{63}$

Taha Toros, Fâik Âli'nin menkûblara karşı muhabbetinin olduğunu, bu sebeple Midilli Mutasarrıflı̆̆ döneminde adaya nefyedilenleri kefaletle serbest bıraktığını ve bu suretle derin muhabbetlerini kazandığını söyler. ${ }^{64}$

Fâik Âli, Midilli'den ayrıldıktan sonra, her ikisi de şiddetli ìttihatçı muhalifi olan ${ }^{65}$ Kamil Paşa'nın sadrazamlığı ve Ahmed Reşid (Rey) Bey'in Dâhiliye Nazırlığı yaptığı ${ }^{66}$ ve

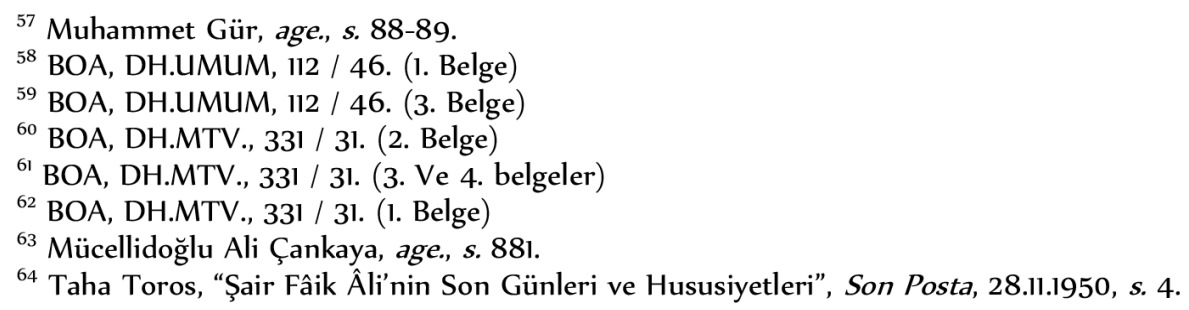


Balkan Harbi fecaatlerinin yaşandı̆̆ günlerde ${ }^{67}$ (16 Ekim 1912) önemine binaen Kırşehir sancağı mutasarrıflığına tayin olunur. ${ }^{68}$ ibnülemin, Fâik Âli'nin Kırşehir'e gitmediğini söylese ${ }^{69}$ de Fâik Ẩli: “Eylül 1912'de, Balkan Harbi'nin başlaması üzerine Kırşehir Mutasarrıflı̆ı̆na nakledilerek Midilli'den ayrıldım. Temmuz 1913'de sıhhî sebeplerle Kırşehir Mutasarrıflı̆ğ'ndan istifa edip İstanbul'a geldim.” der. ${ }^{70}$ Mevcut arşiv belgeleri ise Fâik Âli Bey'in aradan hayli müddet geçtiği hâlde görev yerine gitmemiş olmasına binaen müstafi addedildiğini ve yerine Yozgat sancağı mutasarrıflı̆̆ından ayrılma Hüseyin Kenan Paşa'nın tayin edildiğini ifade eder. ${ }^{71}$ Bu bilgiler ışı̆̆ında Fâik Âli'nin Kırşehir'e gidip göreve başladığını, daha sonra sıhhi sebeplerle -muhtemelen- rapor alıp görevinden ayrıldığını ve raporun süresi bittikten sonra görevine dönmediğini ve sürecin sonunda istifa ettiğini veya müstafi sayıldığını düşünebiliriz.

\section{g) Beyoğlu Mutasarrıflı̆ı}

Yaklaşık altı ay merkeze çekilen Faik Âli Bey, İttihatçıların Babıâli Baskını'ndan ${ }^{72}$ (23 Ocak 1913) sonra kurulan Mahmut Şevket Paşa kabinesinde aktif göreve döner. Adil Bey içişleri Bakanı olunca Fâik Ali de 9 Nisan 1913 tarihinde Beyoğlu mutasarrıflı̆̆ına atanır. ${ }^{73}$ Göreve başladıktan bir müddet sonra polis müdürü Murad Bey ile aralarında "idari ve içtihadî" sebeplerle ihtilaflar çıkmaya başlar. Bu ihtilaflardan birincisi yük arabalarının Beyoğlu caddesinden geçirilmemesiyle ilgili zabıta işlerinden kaynaklanır. ${ }^{74}$ Bir diğeri, İtalyan konsolosluğunun Faik Âli Bey'den talep ettiği, Fâik Âli Bey'in de teslimi konusunda söz verdiği İtalyanlarla ${ }^{75}$ ilgilidir. İtalyan konsolosluğu, bir ay boyunca gözetlediği ve istanbul'dan çıkarılmalarını kararlaştırdığı birkaç İtalyan'ın yakalanması için Beyoğlu Kaymakamlığı'ndan on tane polis memuru ister. Fâik Âli de yardımcı

\footnotetext{
${ }^{65}$ Yılmaz Öztuna, Avrupa Türkiyesini Kaybımız: Rumeli'nin Elden Çıkışı. i̇stanbul: Babıâli Kültür Yayıncılı̆̆ı, 2006, s. 143.

${ }^{66}$ Sinan Kuneralp, Son Dönem Osmanh Erkân ve Ricali (1839-1922), (Prosopografik Rehber). istanbul: îsis Ltd. (1. Baskı 1999), 2. Baskı, 2003, s. 1,3.

${ }^{67}$ Birinci Balkan Savaşı 18 Ekim 1912'de başlar. Yunanlılar; 20 Ekim'de Bozcaada'yı, 2l Ekim'de Limni'yi, 21 Kasım'da da Midilli'yi işgal ederler. Midilli'deki az sayıdaki Türk askeri, donanmanın imdatlarına geleceği ümidiyle Türk bayrağını indirmemek için direnir. Fakat sonunda açlığa dayanamazlar ve 20 Aralık 1912'de kale Yunanlılara teslim olur. Yılmaz Öztuna, age., s. 106-127.

${ }^{68}$ BOA, i.DH., 1496 / 38. (1. Belge). Başka bir belgede 19 Ekim 1912 (8 Zilkade 1330) tarihinde tayin edildiği söylenir. BOA, i..DH..., 1496 / 1330/Za-47.

${ }^{69}$ ibnülemin, age., s. 360.

${ }^{70}$ Mücellidoğlu Ali Çankaya, age., s. 881.

${ }^{71}$ BOA, i.DH., 1497 / 20. (I. Belge); BOA, DH.SAiD, Sıra No: 0112, s. 413-414.

${ }^{72}$ Ayrıntılı bilgi için bk. Yılmaz Öztuna, age., s. 138-145.

${ }^{73}$ BOA, i..DH.., 1498 / 1331/Ca-0I.; BOA, i.DH., 1498 / 42. (2. Belge); BOA, DH.SAID, Sıra No: 0112 , s. 413-414.; BOA, BEO, 4162 / 312088. Fâik Âli Bey ise 14 Kasım 1913'te Beyoğlu Mutasarrıflı̆̆ına tayin olunduğunu söyler. Mücellidoğlu Ali Çankaya, age., s. 881 .

${ }^{74}$ BOA, DH.MTV, $12 / 14$. (23. Belge)

${ }^{75}$ BOA, DH.MTV, 12 / 14. (9. Belge)
} 
olması için Polis Müdürü Murad Bey'den yardım ister. Fakat Murad Bey, muhtelif bahanelerle kaymakamın talebine olumsuz cevap verir. ${ }^{76}$

Diğer bir mesele; Fâik Âli Bey'in mutasarrıflık kapısı önünde ve kendi hizmetinde bulundurmak için istediğ $\mathrm{i}^{77}$ bir polis memurunun kendisine verilmemesidir. Beyoğlu Polis Müdürü Murad Bey, 27 Mayıs 1913 tarihli ifadesinde bu hususun, Müdür-i Umumî Azmi Bey'in de bilgisi dâhilinde olduğunu ifade eder. ${ }^{78}$

ihtilafin bir diğer sebebi ise Fâik Âli Bey'in, polis müdüründen doğrudan doğruya kendisine tâbi olmasını ${ }^{79}$ ve -siyasî olabileceği ihtimaliyle- her meseleden kendisini haberdar etmesini istemesidir. ${ }^{80}$ Murad Bey ise istanbul'un özel kanunlara tabi olmasından ${ }^{81}$ hareketle mutasarrıftan bağımsız hareket etmeye çalışır. Fâik Âli Bey de bu durumdan rahatsiz olur.

Ayrıca Beyoğlu'ndaki Lüksemburg gazinosunun kullanımıyla ilgili olarak da Fâik Âli Bey ile Murad Bey arasında anlaşmazlık çıkar. Fâik Âli, bu gazinodaki sinemanın haftada bir iki defa Müslüman kadınlarınca da kullanılmasını sinema direktörüyle karara bağladığı hâlde, Murad Bey, birtakım mahzurlardan dolayı buna izin vermez. ${ }^{82}$

Murad Bey, 27 Mayıs 1913 tarihli ifadesinde, ihtilafın sebepleri arasında Fâik Âli Bey'in Asmalı Mescit Sokağı'nda yemek yediği lokantanın üstünde araba bulundurulmamasına dair verdiği emrin zaruretlerden dolayı tatbik edilememesini de sayar. ${ }^{83}$ Aralarındaki ihtilafları çözmek için Fâik Âli Bey, Murad Bey'i davet eder. Fakat Murad Bey, davete icabet şeklini ve davetin sebeplerini bildirmediği gerekçesiyle mutasarrıfın davetine icabet etmez. Bunun üzerine Fâik Âli Bey, “idare-i Umumiye-i Vilayet Kanunu"nun verdiği salahiyete dayanarak Murad Bey’i görevinden alır ${ }^{84}$ ve başka birisi atanana kadar Muhtar Bey'in vazifeye vekâlet etmesini ister fakat o da vekâleti kabul etmez. ${ }^{85}$ Hâlbuki değil polis müdürü, polis memurlarının bile azli ancak valiler tarafından yapılabileceği için Fâik Âli'nin icraatı "gayr-ı kanunî" bulunur. ${ }^{86}$ Fâik Âli, Murad Bey'i azle teșebbüsle kalmaz bir de Jandarma Tabur Kumandanlı̆̆ından talep ettiği iki askeri Polis Müdüriyetinin kapısına koyarak Murad Bey'i dairesine girmekten

\footnotetext{
${ }^{76}$ BOA, DH.MTV, 12 / 14. (11. Belge); BOA, DH.MTV, 12 / 14. (20. Belge); BOA, DH.MTV, 12 / 14. (19. Belge); BOA, DH.MTV, 12 / 14. (20. Belge)

77 BOA, DH.MTV, 12 / 14. (4. ve 24. Belgeler)

${ }^{78}$ BOA, DH.MTV, 12 / 14. 9. Ve 11. Belgeler.

${ }^{79}$ BOA, DH.MTV, $12 / 14$. (9. Belge)

${ }^{80}$ BOA, DH.MTV, 12 / 14. (12. Belge)

${ }^{81}$ Beyoğlu Mutasarrıflı̆̆ından Beyoğlu Polis Müdüriyetine yazılan 2l Mayıs 1913 (8 Mayıs 329) tarihli ve 286 numaralı tezkirenin suretinden Fâik Âli Bey'in bu hususu bildiğini anlıyoruz. BOA, DH.MTV, 12 / 14. (2. Ve 22. Belgeler)

${ }^{82}$ BOA, DH.MTV, $12 / 14$. (11. Belge)

${ }^{83}$ BOA, DH.MTV, $12 / 14$. (11. Belge)

${ }^{84}$ BOA, DH.MTV, $12 / 14$. (5. ve 26. Belgeler)

${ }^{85}$ BOA, DH.MTV, $12 / 14$. (25. Belge)

${ }^{86}$ BOA, DH.MTV, $12 / 14$. (1/1. Belge)
} 
men ve celbi için emir verir. ${ }^{87} \mathrm{Bu}$ durumdan rahatsız olan İstanbul Polis-i Umumiyye Müdüriyeti, Beyoğlu gibi bir mevkide bulunan mutasarrıfin bu şekilde "nezaketsizce, daha doğrusu hilaff-ı kanun ve akıl muamelede” bulunmasını kınar ve polis müdürünün şahsi ve mevki haysiyetini rencide etmesinden dolayı Fâik Âli'nin kaymakamlı̆̆a devamının uygun olmayacağını içişleri Bakanlığına arz eder. ${ }^{88}$ içişleri Bakanlığı, 27 Mayıs 1913 tarihinde Fâik Âli Bey'in ifadesini alır. ihtilafların halledilemeyeceğini anlayan Fâik Âli Bey, 9 Haziran 1913 tarihinde, istifa eder; ${ }^{89} 14$ Haziran 1913 tarihinde de görevinden azledilir. ${ }^{90}$ Fâik Âli Bey'in karşılaştığı problemlerin vesikalarda görünmeyen sebeplerinin de olduğu anlaşılıyor. Fâik Âli, particilik ve hizipçilik çatışmalarının had safhada olduğu bu dönemde ne İttihatçı ne de Halaskârân grubundandır. O nedenle Halaskârların hamisi olduğu iddia edilen ${ }^{91}$ İçişleri Bakanı Ahmed Reşid Rey ile de çok mutaassıp bir İttihatçı olan ${ }^{92}$, zamanın Emniyet Müdürü Azmi Bey ile de anlaşamaz.

\section{h) Kütahya Mutasarrıfliğı}

Fâik Âli, bir buçuk ay sonra, (31 Ağustos 1913) İsmail Kemal Bey'in yerine Kütahya Mutasarrıflı̆ına atanır. ${ }^{93}$ iki ay sonra, (29 Ekim 1913) tayini Üsküdar mutasarrıflı̆̆ına çıkar. ${ }^{94}$ Arşiv kaynaklarında Üsküdar'daki icraatlarıyla ilgili fazla bir belge yoktur. Bununla birlikte Dâhiliye Nezareti Memurîn Müdüriyetinin 13 Ocak 1914 tarihinde Şurayı Devlet Riyasetine gönderdiği yazıda Fâik Âli Bey'in birikmiş izinlerinin kullanımının bahis mevzuu edildiği görülmektedir. ${ }^{95}$ Buna göre, Fâik Âli Bey'in o dönemde birikmiş olan üç aylık iznini kullanmış olması muhtemeldir. 11 Ocak 1915'te ikinci defa Kütahya Mutasarrıflı̆̆ına atanır. ${ }^{96}$ Fâik Âli'nin Kütahya Mutasarrıflı̆̆ dönemi, Osmanlı Devleti'nin siyasi, idari ve iktisadi her anlamda en problemli zamanına tekabül eder. Birinci Dünya Savaşı'na girmiş olan Osmanlı Devleti, bir taraftan muhtelif ve müteaddit cephelerde savaşırken diğer taraftan iç problemleriyle uğraşır. Bir taraftan Cemal Paşa güneyde (28 Ocak - 3 Şubat 1915) İngilizlere karşı bir kanal harekâtına girişir; diğer taraftan Osmanlı ordusu Çanakkale'de (19 Şubat - 18 Mart 1915) başarılı bir deniz

\footnotetext{
${ }^{87}$ BOA, DH.MTV, 12 / 14. (10. Belge)

${ }^{88}$ BOA, DH.MTV, 12 / 14. (9. Belge)

${ }^{89}$ BOA, DH.MTV, 12 / 14. (36. Belge)

${ }^{90}$ BOA, i.DH., 1499 / 35. (1. Belge); BOA, DH.MTV., 12 / 14. Sicill-i Ahval Defterinde 15 Haziran 1913 (2 Haziran 329) tarihinde azledildiği yazıyor. BOA, DH.SAiD, Sıra No: 0112, sayfa: 413-414.; Fâik Âli Bey ise zühulle: "(Dâhiliye Nezareti ile) İdari ve içtihadî bir ihtilaf sebebiyle 30 Aralık 1913'de Beyoğlu Mutasarrıflğından da istifa ederek ayrıldım.” Diyor. Mücellidoğlu Ali Çankaya, age., s. 881.

${ }^{91}$ Y 1 lmaz Öztuna, age., s. 175.

${ }^{92}$ Yılmaz Öztuna, age., s. 169.; Fatih Kerimî, (Hazırlayan: Fazıl Gökçek). İstanbul Mektupları, İstanbul: Çağrı Yayınları, 2001, s. 188.

${ }^{93}$ BOA, i..DH.., 1500 / 1331/N-17.; BOA, i.DH., 1500 / 48. (2. Belge); BOA, DH.SAiD, Sira No: 0112, s. $413-414$.

${ }^{94}$ BOA, i.DH., 1501 / 49. (2. Belge); BOA, i..DH.., 1501 / 1331/Za-22.; BOA, BEO, 4227 / $316958 . ;$ BOA, DH.SAID, Sira No: 0112, s. 413-414.

${ }^{95}$ BOA, ŞD, 39 / 34. (3. Belge)

${ }^{96}$ BOA, i.DH., 1512 / 34. (2. Belge) Başka bir belgede tayin tarihi, 13 Ocak 1915 (26 Safer 1333) olarak gösterilir. BOA, BEO, 4332 / 324832.
} 
savunması yapar. Nisan ve Mayıs aylarında ise Ocak ayında başlayan fakat Rusların taarruzlarıyla daha da kızışan Ermeni isyanları Bitlis ve Van başta olmak üzere bütün doğu vilayetlerini kasıp kavurur. Bu kritik ortamda Içişleri Bakanı Talat Bey, çok tartışılacak iki karara imza atar. Bunlardan ilki Ermeni komite merkezlerinin kapatılması, elebaşlarının tutuklanması ve her türlü belgelerine el konulmasını talep eden 24 Nisan 1915 tarihli “Tutuklama Kararı”; diğeri de mülki ve askerî âmirlere uygun görecekleri kişileri geçici olarak başka yere nakletme yetkisi veren, 27 Mayıs 1915 tarihli "Tehcir Kanunu"dur.

Tehcir Kanunu çıkmadan önce, Süleyman Nazif, kardeşi Fâik Âli'yi Ermenilere karşı bir barbarlığa katılmaması ve aile şereflerine leke sürmemesi konusunda uyarır. Haksızlıklara tahammül edemeyen ve kanunlara riayetkâr olan Fâik Âli, Kütahya'ya gelir gelmez şehrin ileri gelenleriyle İttihatçı liderleri toplayarak Ermeniler hakkındaki fikirlerini yazılı olarak beyan etmelerini ister. Fâik Âli, Kütahya Ermenilerinin zararsız olduklarını beyan eden bu kâğıtları saklar. Tehcir hadisesi başlayıp da İttihatçılar kendisinden Ermenilerin sürgün edilmesini isteyince imzaladıkları evrakları çekmecesinden çıkarır ve "Ermeniler yakın zamana kadar iyi, dürüst insanlardı da şimdi mi vatan haini oldular? O zaman hükümeti aldattıysanız eğer, suçlu olursunuz. Yok, eğer şimdi suçsuzlara iftira ediyorsanız kesinkes vicdansızlıktır." Diyerek onları kovar. Fakat itttihatçılar fikirlerini değiştirmez. Bir taraftan şehrin ayak takımını sokaklarda "Gâvur Mutasarrıf" diye bağırtırken diğer taraftan Fâik Âli'yi "Ermeni dostu" ithamıla Talat Paşa'ya şikâyet ederler ${ }^{97} 1915$ Kasımının ortalarında Talat Paşa, telefonla Fâik Âli'den Ermenileri Mezopotamya'ya sürmesini isterse de Fâik Âli Bey, bütün delilleriyle Kütahya Ermenilerinin masumiyetinden bahisle böyle bir şeyi uygulamanın vicdanına ters düştüğünü ve israr ederlerse istifa edeceğini ifade eder. Bunun üzerine Talat Paşa geri adım atar. ${ }^{98}$ Fâik Âli'nin tehcir yolundaki Ermenileri Kütahya'da iskân ettirmesi, Ermenileri tehcir etmek isteyen İttihatçı polis müdürünü sürmesi, korku sâikiyle sünnet olup İslamlaşmak isteyen Ermenilere teminat vermesi, hatta din değiştirmelerinin önüne geçmesi, yine idarecilerin gözüne girmek için Ermenilerin Kızılay'a hibe ettikleri parayı Ermeni fakirlerine dağıtması ve Ermenilerin kendi okullarını açmalarını teşvik ederek Kütahya'da kalıcı olduklarının garantisini vermesi ${ }^{99}$, Fâik Âli Bey'in Ermeniler tarafından "âdil", "hakperest" ve "vicdanlı" bir vali olarak tanınmasına ve minnetle anılmasına sebep olur. Bu minnet duygusunun tezahürü olarak Kütahya Ermenileri, Fâik Âli Bey için Kütahya Kilisesi'nde bir Şükran Kitabesi dikerler. Ermenilerin bu cemilesinden çok duygulanan Fâik Âli Bey, Tasvîr-i Efkâr gazetesi kanalıyla Kütahya Ermeni murahhas vekili Sehak Efendi'ye yazdığı mektupta hem teşekkürlerini ifade eder hem de tehcir hâdisesinin birkaç yüz kişinin işi olduğunu ve Türk halkının ekseriyetinin ve Kütahya Türklerinin de kendisi gibi davrandığını ve Ermenilere her zaman yardımcı olduğunu

\footnotetext{
${ }^{97}$ Sarkis Seropyan, "Vicdanlı Bir Türk Valisi: Fâik Âli Ozansoy". Imparatorluğun Çöküş Döneminde Osmanlı Ermenileri Bilimsel Sorumluluk ve Demokrasi Sorunları: 23-25 Eylül 2005, İstanbul: İstanbul Bilgi Üniversitesi Yayınları, Mart 2011, s. 295-296.

${ }^{98}$ Sarkis Seropyan, age., s. 295-296.

${ }^{99}$ Sarkis Seropyan, age., s. 289-297.
} 
$116^{*}$ TAED 50

Sinan ÇiTÇi

hatırlatarak bu hususun da bütün dünyaya duyurulmasını kendilerinden rica eder. ${ }^{100}$ Fâik Âli'nin Ermenilere karşı muamelesi, Nahid Sırrı ve Taha Toros gibi pek çok Türk aydını tarafindan da takdirle karşılanır. ${ }^{101}$

1916 Mart'inda Gelibolu mutasarrıfi ibrahim Bey ile Kütahya mutasarrıfı Fâik Âli Bey'in becayişleri düşünülür. ${ }^{102} 16$ Mart 1916'da Memurîn Müdüriyetinden Faik Âli Bey'e "Gelibolu'ya tahviliniz tensib olunuyor. Muvafakatınızın işarı" şeklinde bir telgraf çekilir. ${ }^{103}$ Bir gün sonra da Gelibolu'ya atanır ${ }^{104}$ fakat Gelibolu'ya gitmeyerek istifa eder. ${ }^{105}$ Süleyman Nazif in 17 Haziran 1916 tarihinde Nişantaşı'ndan kardeşine gönderdiği mektuba ${ }^{106}$ bakılacak olursa Fâik Âli, bir müddet eşinin memleketi Bursa'da istirahat eder. Kısa bir süre sonra, Fâik Âli Bey (22 Haziran 1916) Gelibolu mutasarrıflığından da azledilir. ${ }^{107}$

\section{1) Dâhiliye Nezâreti Heyet-i Teftişiyye Kalemi Müdürlüğü}

O sırada Dâhiliye Nezareti Heyet-i Teftişiyye Kalemi Baş kitabeti ile muavinliği lağvedilip yerine "Heyet-i Teftişiyye Kalemi Müdüriyeti" adıyla yeni bir müdüriyet kurulur. Faik Âli Bey, 10 Mart 1917'de bu müdürlüğe atanır. ${ }^{108}$ Bir sene geçmeden Fâik Âli Bey, 14 Ocak 1918'de Kars mutasarrıflı̆ına atanır. ${ }^{109}$ Fakat mevcut kaynaklarda Kars'ta mutasarrıflık yaptığına dair bir bilginin olmaması, bu tayinin de kâğıt üstünde kaldığını gösterir. Zaten kendisi de hâl tercemesinde Kars'tan hiç bahsetmez."10

\section{i) ikinci Defa Beyoğlu Mutasarrıflığı}

Fâik Âli, 18 Ağustos 1918 tarihinde, tekrar Beyoğlu mutasarrıflı̆ına atanır." Mondros Ateşkes Antlaşmasının imzalanmasından yaklaşık bir ay önce (22 Eylül 1918) eski Beyoğlu mutasarrıfının talebi üzerine" bombardımanlarından meydana gelen hasar hakkında tahkikat yapmak üzere teşekkül eden Tedkik-i Hasarat Komisyonu" riyasetine getirir." Fakat bu vazifedeyken de Beyoğlu Mutasarrıflı̆ı devam eder. Nitekim Halit Fahri, 16 Kânunusani 1919'da Fâik Âli'nin

\footnotetext{
${ }^{100}$ Fâik Âli, "Fâik Âli Bey’in Bir Mektubu”, Tasvîr-i Efkâr, 7 Rebiyülâhir 1337 / 9 Kanunusani 1335 (1919), s. 1.

${ }^{101}$ Nahid Sırrı Örik, agg., s. 2.; Taha Toros, "Şair Fâik Âli'nin Son Günleri ve Hususiyetleri”, Son Posta, 28.11.1950, s. 4.

${ }^{102}$ BOA, I...DUiT, 42 / 23; BOA, BEO (Dahiliye; MTV/80), 4405 / 330356

${ }^{103}$ BOA, DH.ŞFR., 62 / 37.

${ }^{104}$ BOA, DH.ŞFR., 513 / 57.; BOA, i.DUiT, 42 / 23.

${ }^{105}$ Mücellidoğlu Ali Çankaya, age., s. 881.; ibnülemin, age., s. 360.

106 "Aziz ve Kıymetli Hatıralardan: Süleyman Nazif in Fâik Âli'ye Bir Mektubu", Marmara, $S$ ।, Y1l:

1, 15 Nisan 1936, s. 4.

${ }^{107}$ BOA, i.DuiT, 42 / 29.

${ }^{108}$ BOA, BEO, 4459 / 334383.; BOA, i...DUiT, 39 / 59.

${ }^{109}$ BOA, DH.ŞFR, 602 / 79.

${ }^{110}$ Mücellidoğlu Ali Çankaya, age., s. 880-881.

"' BOA, i..DUiT, 42 / 94.; BOA, BEO, 4529 / 339633

112 BOA, DH.i.uM, 21-1 / 72. (2. Belge)

${ }^{113}$ BOA, DH.i.UM, 21/-1 / 72.; BOA, DH.i.uM, 21-1 / 72. (1. Belge)
} 
Beyoğlu Mutasarrıfı olduğunu, ilk sayısını çıkaracağı Şair Nedim isimli dergide yayımlanmak üzere kendisinden şiir istemeye gittiğini ve Fâik Âli’nin “O, Bir Şi'r-i Kudrettir" isimli şiirini verdiğini nakleder."

\section{j) Diyarbakır Valiliği}

Doğu ve Güneydoğu Anadolu'nun en önemli şehirlerinden olan Diyarbakır, Mütareke'den sonra farklı bir ehemmiyet kazanır. Etnik ve dinî çeşitliliği itibarıyla Amerikalıların musavver Ermeni devletine, İngilizlerin de Kürt devletine dâhil etmek istedikleri şehir, o günlerde tam bir keşmekeş içindedir. Uygun bir vali bulunamadığı için Diyarbakır Valiliği'ne de 17 Ocak 1918'den beri Ergani mutasarrıfi Mustafa Nadir Bey vekâlet etmektedir. ${ }^{115}$ Mustafa Nadir Bey, 11 Haziran 1919 tarihinde, İçişleri Bakanlığına gönderdiği yazıda, bir seneye yakın bir zamandan beri, her türlü mahrumiyet içinde yürüttüğü görevinde âciz kaldığını beyan ederek mümkünse İstanbul civarında bir mutasarrıflığa, değilse asli görev yeri olan Ergani'ye avdet ettirilmeyi talep eder. ${ }^{116}$ Siyasi konjonktürün ve bölgenin nezaketinin farkında olan İstanbul Hükümeti, hem Binbaşı Norwill gibi ecnebi casusların emellerini boşa çıkaracak hem de saygınlığıyla bölge halkının hissiyâtını İstanbul'a bağlayacak "iktidar ve liyakat sahibi” bir şahıs olarak Fâik Âli Bey'i düşünür. Çünkü Fâik Âli Bey, Diyarbakır'ın tanınmış bir ailesinden olması hasebiyle bölge halkına yakın bir isimdir. Terceme-i hâlinde yazdı̆̆ üzere belli seviyede Arapça ve Kürtçe bilir. Diğer taraftan devlete sıkı sıkıya bağlı, hükümetin emir ve görüşlerinden dışarıya çıkmayacak bir insandır. ${ }^{17}$ Bütün bunların yanı sıra en zor bölgelerde çalışmış, tecrübeli bir mülkiyelidir. Bu düşüncelerle 9 Haziran 1919 tarihinde Sadrazam Damat Ferid Paşa'nın riyasetindeki Bakanlar Kurulu kararıyla Faik Âli Bey, Diyarbakır'a vali olarak atanır ${ }^{118}$ ve Kürt aşiret reislerine verilmek üzere hükümetçe yazılmış birtakım özel mektupları da yanına alarak yola çıkar. ${ }^{119} 19$ Haziran 1919 tarihinde Dâhiliye Nezâreti'nden Diyarbakır Vilayeti Vekâletine gönderilen yazıda Fâik Âli Bey'in yola çıktığı ve görev mahalline ulaşana kadar vekâlete devam edilmesi ifade edilir. $^{\prime 20}$ Faik Âli Bey'in Konya'dan Mardin'e gidişi için İngilizler tarafindan bir vagon tahsis edilir ve bu durum 23 Haziran 1919 tarihinde çekilen telgrafla Konya Valiliğine bildirilir. ${ }^{21}$ Valilik de durumu istasyon müdürüne haber verir. İstasyon müdürünün ücret meselesini sorması üzerine, Konya Valiliği, 24 Haziran 1919 tarihinde Dâhiliye Nezareti Şifre Kalemine yazdığı yazıda Fâik Âli Bey'in henüz gelmediğini beyan ile vagon ücretinin neden ibaret olacağını sual eder. ${ }^{122} 26$ Haziran 1919 tarihinde, Dâhiliye Nezâreti Hususî Kaleminden Konya Valiliğine çekilen ikinci telgrafla vagonun İngiliz memurları

\footnotetext{
${ }^{114}$ Halit Fahri Ozansoy, Edebiyatçılar Geçiyor: İstanbul: Türkiye Yayınevi, 1967, s. 188-189.

${ }^{115}$ Kâmil Erdeha, Milli Mücadelede Vilayetler ve Valiler. İstanbul: Remzi Kitabevi, 1975, s. 144.

${ }^{116}$ BOA, DH.KMS, 53-1 / 71. (2. Belge)

${ }^{117}$ Kâmil Erdeha, age., s. 147.

${ }^{118}$ BOA, i...DuiT, 41 / 91.; BOA, MV, 251 / 12.

${ }^{119}$ Kâmil Erdeha, age., s. 147.

${ }^{20}$ BOA, DH.ŞFR., 100 / 154.; BOA, DH.KMS, 53-1 / 71. (1/1. Belge)

${ }^{121}$ BOA, DH.ŞFR, 100 / 173.; BOA, DH.KMS, 53-1 / 91. (1/1. Belge)

${ }^{122}$ BOA, DH.KMS, 53-1 / 91. (3. Belge)
} 
tarafından tahsis edildiği, ücretinin Fâik Âli Bey tarafından verileceği, ${ }^{123}$ valilikçe herhangi bir ücret verilmesi lazım gelmediği ifade edilir. ${ }^{124}$ Fâik Âli Bey; Konya, Adana, Halep, Mardin üzerinden Diyarbakır’a gider. Günün şartlarından kaynaklanan sebeplerle Adana ve Halep'te beklemek zorunda kalır. Fâik Âli Bey'in yolculuk için kendisine avans olarak verilen beş yüz lira harcırahın yetersiz olduğunu ifade eden ve arttırılmasını talep eden dilekçesine ${ }^{125}$ ve ilgili belgelere ${ }^{126}$ baktığımız zaman, bu seyahatin çok güvensiz, yorucu, sıkıntılı ve masraflı geçtiğini söyleyebiliriz. Fâik Âli Bey, 5 Temmuz 1919'da Diyarbakır'da göreve başlar. ${ }^{127}$ Aynı günlerde, Mustafa Kemal Paşa'nın emriyle Erzurum Kongresi için Anadolu'da yoğun bir faaliyet vardır. Vilayetler kendi delegelerini seçerken Diyabakır'dan da dört delege seçilir. Mustafa Kemal Paşa'nın talepleri ile ìstanbul Hükümeti'nin tarz-1 siyaseti arasında kalan Fâik Âli Bey, nasıl hareket edeceği ile ilgili Dâhiliye Nezareti'nden bilgi talep eder. ${ }^{128} 9$ Temmuz 1919 tarihinde, İstanbul Hükümeti, Mustafa Kemal Paşa'nın isteklerini yerine getirmemesi yönünde emir verince ${ }^{129}$ Fâik Âli Bey, bu delegelerin 21 Temmuz'daki Erzurum Kongresi'ne katılmasını engeller. Fakat 1919 Eylül'ünün başında meydana gelen Ali Galip olayıyla birlikte Mustafa Kemal Paşa'nın etrafinda toplanan ekibin herhangi bir çıkar mülahazası gözetmeden vatana ve millete hizmet ettiği anlaşılınca Fâik Âli Bey'in kanaati değişir. Fâik Âli Bey, halazadesi ihsan Hamit Bey'i -gecikmeli de olsa- Sivas Kongresi'ne delege olarak gönderir. Bu durumdan memnun olan ve Fâik Âli Bey'e teşekkür eden Mustafa Kemal Paşa, bir cemile olarak ihsan Hamit Bey'i Heyet-i Temsiliyye üyeliğine seçer. Fakat Fâik Âli'nin ilk andaki mütereddit tavrı ve bilahare iç̧işleri Bakanlı̆̆ Müsteşarlığına getirilmesi, Mustafa Kemal tarafından evvelemirde "kuva-yı milliye muhalifi" olarak algılanmasına ve şüpheli görülmesine sebep olur. Mustafa Kemal, Rauf Bey'in verdiği malumata istinaden, ordu komutanlarına gönderdiği 20 Şubat 1920 tarihli genelgede hükümetin millî mücadeleye muhalefetinden dolayı Fâik Âli Bey'i müsteşarlığa atadığını söyler.

Maatteessüf Sadrazam vaziyeti idrâk edecek bir mâhiyette görülmediği gibi Dâhiliye Nâzırı́n!n da Istanbul Polis Müdürü ile Jandarma kumandanlarının tebdillerine ve ecnebi hükümetlerinin âlet-i icraatı olan bu makâmâtın emin ellere tevdiine dair hiçbir kudretleri olmadığı anlaşıld. Acz ve meskeneti malum olan Müsteşar Keşfi Bey'i Bursa'ya vali yaptığın ve harekât-ı milliyyeye muhalefetinden dolayı Diyarıbekir'den kaldırılan Fâik Âli Bey'i de Dâhiliye Müsteşarı tayin ettiğini ilaveten söyledi. Hulasa, netice itibarile bu gayr-1 müdrik, âciz heyetin âmâl-i milliyyeye muvafik hareket edecekleri heyetçe memûl değildir. ${ }^{130}$

\footnotetext{
${ }^{123}$ BOA, DH.ŞFR, $100 / 190$.

124 BOA, DH.KMS, 53-1 / 91. (2/1. Belge)

${ }^{125}$ BOA, ŞD. 39 / 34.

${ }^{126}$ BOA, DH.KMS., 60/-1 / 39.; BOA, MV., 221 / 41.

${ }^{127}$ Kâmil Erdeha, age., s. 145, 147.

${ }^{128}$ Yunus Nadi, Kurtuluş Savaşı Anıları. ístanbul: Çağdaş Yayınları, 1978, s. 107.

129 Yunus Nadi, age., s. 108.

${ }^{130}$ Kemal Atatürk, Nutuk (Vesikalar). C 3, ìstanbul: Milli Eğitim Basımevi, 1982, s. 1207.
} 
Bununla birlikte tam bir muhalif olarak görülmediği için hem hakkında "cevaz-ı istihdam / çalıştırılabilir" kararı çıkar hem de "Yüzellilikler Listesi"ne alınmaz. ${ }^{131}$ Kâmil Erdeha bu konuyu şöyle özetler:

Bu, şüphesiz madalyonun bir yüzüdür. Madalyonun diğer yüzü ise Fâik Ali Bey ile Mustafa Kemal arasında bir dialogun kurulamamasıdır: Fâik Âli Bey, Mustafa Kemal'in aradı̆̆̆ vali değildi. Fâik Âli Bey, devletini, milletini çok sevmekle birlikte yetiştiği çevre, karakteri, onun, Mustafa Kemal'in eylemlerine ayak uydurmasını engellemişti. ${ }^{132}$

6 Kasım 1919 tarihinde iç̧işleri Bakanlığı'ndan Fâik Âli Bey'e “acil” koduyla bir yazı gönderilir ve Bitlis Valiliği'ni kabul edip etmeyeceği sorulur. Nasıl bir cevap verdiğini bilememekle birlikte Bitlis'e gitmediğini ve Diyarbakır'da kısa bir süre görev yaptığını rahatlıkla söyleyebiliriz. Nitekim kısa bir süre sonra, tedavi için izin dilekçesi verir. Bu talebe karşılık, 21 Aralık 1919 tarihinde, onun yerine Diyarbakır'a, Bitlis eski valisi Hüseyin Mazhar Bey atanır. ${ }^{133}$ Faik Âli Bey de İstanbul'a döner.

Kendisi Diyarbakır Valiliği macerasını şöyle anlatır: “... 1. Sınıf Diyarbekir Valiliği’ne tayin edildim. Doğduğum bir yerin Valiliğine tayinim mühim sebeblere mübtenîdir. $\mathrm{O}$ zaman Mütareke'den henüz Sulh hâline intikal edilmemişdi. I. Dünya Harbi'nin birtakım pürüzlü ve dikenli meseleleri karşısında Memleket çok huzursuzdu. Ermeni Meselesi, Kürt Meselesi, Amerikan Mandası vs. gibi... Diyarbekir'e gittiğimden altıbuçuk ay sonra o havâlide, o meseleler artık kalmamış olduğundan, vazifemin tamam olduğuna kanaatle istifa edip İstanbul'a geldim." 134 Taha Toros ise onun kısa Diyarbakır valiliğini "başarısız" kelimesiyle niteler. ${ }^{135}$

\section{k) Dâhiliye Nezâreti Müsteşarlığı}

O sırada Bursa valisi olan Ebubekir Hâzım Bey, kendisine yapılan Dâhiliye Nâzırlı̆̆ı teklifini kabul edip 1920 Şubat'ında yeni görevine başlayınca ${ }^{166}$ Fâik Âli Bey'e Dâhiliye Nezâreti Müsteşarlığını teklif eder. ${ }^{137}$ Fâik Âli Bey, "büyük devlet adamı ve büyük edîb" dediği Ebubekir Hâzım Bey'in teklifini kabul eder ve 17 Şubat 1920 tarihinde Dâhiliye Nezâreti Müsteşarlığı'na atanır. ${ }^{138}$ Kısa bir zaman sonra Ebu Bekir Hâzım Bey, Kuva-yı Millîye'nin asi olduğunu ilan etmeyip meşruluğuna inandığını belirterek Dâhiliye

\footnotetext{
${ }^{131}$ Fâik Âli'nin Millî Mücadelecilerle olan ilişkileri bu kitabın ilgili sayfalarından özetlenmiştir. Kâmil Erdeha, age., s. 143-155.

${ }^{132}$ Kâmil Erdeha, age., s. 155.

${ }^{133}$ Sinan Kuneralp, Fâik Âli'nin Diyarbakır valiliğinin Ocak 1920'de sona erdiğini, Hüseyin Mazhar Bey'in valiliğinin de Ocak 1920'de başladığını söyler. Sinan Kuneralp, age., s. 29, 72. Kâmil Erdaha ise Fâik Âli Bey'in, 14 Ocak 1920'de istifa ettiğini söyler. Kâmil Erdeha, age., s. 153. Bununla birlikte ilgili arşiv belgesi yeni valinin 21 Aralık 1919'da atandığını gösterir. BOA, MV, 253 / 131.

${ }^{134}$ Mücellidoğlu Ali Çankaya, age., s. 881.

135 Taha Toros, Mâzî Cenneti. İstanbul: iletişim Yayınları, 1992, s. 147.

${ }^{136}$ Abdülkadir Hayber, Ebubekir Hâzım Tepeyran. Ankara: Kültür ve Turizm Bakanlı̆̆ı Yayınları, 1988, s. 10.

${ }^{137}$ Mücellidoğlu Ali Çankaya, age., s. 881.

${ }^{138}$ BOA, i..DUiT, 39 / 87.
} 
Nâzırlığı'ndan istifa edince ${ }^{139}$ yerine, 1920 Nisan'ında Ahmed Reşid Bey getirilir. ${ }^{140}$ Faik Âli, Ahmed Reşid ile anlaşamaz ve 1920 Nisan'ında o görevden de ayrılır. ${ }^{141}$ Fâik Âli Bey: “Bir ay'ı vazife başında ve on beş günü de Zatürrie'den yatakta geçen bu memuriyet son memuriyetimdir." der. ${ }^{142}$ ìstanbul Hükûmeti'nin ilgasından sonra "cevâz-ı istihdam" kararı verilerek mazuliyet maaşı ile açığa çıkarılır. ${ }^{143}$ ibnülemin'in de ifade ettiği gibi bu

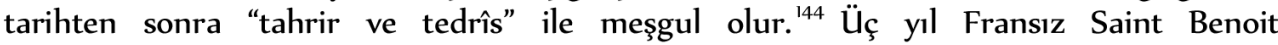
Mektebi'nde Türkçe muallimliği, iki yıl da Mülkiye Mektebi'nde Fransızca okutmanlı̆̆ı yapar. $^{145} 26$ Haziran 1930 tarihinde emekli olur. ${ }^{146}$ Ömrünün geri kalan kısmını yazları genellikle istanbul'da kızının yanında, kışları da Ankara'da oğlu Munis Fâik'in yanında geçirir. Tevfik Fikret ihtifali ${ }^{147}$ ve ilk Türk Dili Kurultay ${ }^{148}$ gibi münferit hadiseler bir tarafa bırakılacak olursa, Fâik Âli'nin emeklilik yıllarında çok göz önünde olmadığı, yakın çevresi ve edebiyatçı dostlarıyla şairane duygular ve hatıralar arasında yaşadığı ve bir ara oğlu Munis Fâik'le birlikte Marmara adlı edebî bir dergi çıkardığı söylenebilir. Son yıllarını bu şekilde geçiren Fâik Âli Bey, 1 Ekim 1950 Pazar günü, gece saat ikiye yirmi kala, Ankara'da Yenişehir Konur Sokak'taki Koral Apartmanı'nda vefat eder. ${ }^{149}$

\section{Sonuç}

Kendisiyle ilgili bilgi ve belgeler incelendiğinde, Fâik Âli'nin ferdî romantizmin şahikalarında, aşırı derecede santimantal ve idealist bir kişiliğe sahip olduğu görülür. Bunun en önemli sebebi, hiç şüphesiz mizacıdır. Il. Meşrutiyet'in tesiriyle yazdığı Midhat

\footnotetext{
139 Abdülkadir Hayber, age., s. 10.

${ }^{140}$ Sinan Kuneralp, age., s. 4.

${ }^{141}$ Raşit Koç, “Fâik Ali Ozansoy'un Şiirlerinin Tematik Olarak İncelenmesi”, Turkish Studies, Volume 5/2 Spring 2010, s. 1245.

${ }^{142}$ Mücellidoğlu Ali Çankaya, age,, s. 881. Aslına halel vermemek için alıntılardaki imla problemlerini düzeltmedik.

143 Mücellidoğlu Ali Çankaya, age., s. 881-882.

144 ibnülemin, age., s. 360.

145 Mücellidoğlu Ali Çankaya, age., s. 882.; Atilla Özkırımlı, Türk Edebiyatı Ansiklopedisi, C 2, Cem Yayınevi, s. 484.

${ }^{146}$ BOA, Fon Kodu: 30..11.1.0, Yer No: 56.17..8. S 5175.; Mücellidoğlu, Temmuz 1930'da emekliye ayrıldığını söyler. Mücellidoğlu Ali Çankaya, age., s. 882. Kenan Akyüz ise 193ı'de emekli olduğunu söyler. Kenan Akyüz, age., s. 415.

${ }^{147}$ Fâik Âli; Abdülhak Hâmid ve Halit Ziya gibi yakın dostlarının da katıldığı, Tevfik Fikret'in doğumunun 100. Y Y $l_{1}$ münasebetiyle Galatasaray Lisesinde tertip edilen ihtifale hastalığı dolayısıyla katılamayacağını bildirir; fakat toplantıda okunmak üzere bir yazı gönderir. "Tevfik Fikret İçin", Cumhuriyet Gazetesi, 25 Kanunuevvel 1931, s. 1,6.

14826 Eylül 1932'de Dolmabahçe Sarayı'ndaki ilk dil kurultayına katılır. Fakat Hüseyin Cahit'le birlikte dilin sadeleşmesine karşı çıkmaları havanın elektriklenmesine sebep olsa da onlar, fikirlerinden vazgeçmezler. Taha Toros, “Atatürk'ün Katıldığı ilk Dil Kurultayları - 1”, Milliyet Gazetesi, 26.09.1982, s. 7. Bundan sonra yapılan beş dil kurultayının hiçbirinde ne konuşmacı ne de dinleyici olarak görülmez. Detaylı bilgi için Türk Dil Kurumu Kütüphanesinin Dil Kurultayları ile ilgili arşivlerine $b k$. http://tdkkitaplik.org.tr/kurultaylar.asp Erişim Tarihi: 29.06.2013.

149 Sevim Karabela, age., s. 23.
} 
Paşa, ${ }^{150}$ Balkan Savaşları münasebetiyle yazdığı Elhân-ı Vatan ${ }^{151}$ ve Çanakkale Muharebeleri için yazdığı Payitahtın Kapısında ${ }^{152}$ adlı eserleri istisna edilecek olursa, en buhranlı zamanlarda bile Fâik Âli'nin, şiirlerinde reel sosyal ve siyasi meselelerden ziyade ideal aşklardan, harikulade tabiat manzaralarından ve yıldızlı semalardan bahsettiğini görürüz. Bu yönüyle ağabeyi Süleyman Naziften bambaşka bir ideale ve karaktere sahiptir. Fâik Âli'nin romantizminin ikinci önemli sebebi ise beslenme kaynaklarıdır. Çok erken yaşta Namık Kemal ve Abdülhak Hâmid gibi romantik şairlerin eserleriyle karşılaşır. Daha ziyade Hâmid'in ferdî romantizminin etkisinde kalır. Bu etki, Fâik Âli'nin sanatına müspet, yöneticilik vasfına ise menfi tesir eder. O nedenledir ki Fâik Âli, şiirleriyle tanınıp takdir edildiği kadar yöneticiliğiyle tanınıp takdir edilmez.

Memuriyet hayatı boyunca devlet ve millet sevgisi, kanunlara bağ $l_{1} l_{1} \breve{g}_{1}$, hakperestliği, dürüst, titiz ve fedakârâne çalışmalarıyla ilk etapta aranan, gedik kapatan ve problemli noktalara gönderilen bir insan olarak karşımıza çıkar. Bunda, Mekteb-i Mülkiyye mezunu olmasının da büyük tesiri vardır. Bununla birlikte sosyal ve siyasi yozlaşmanın her yere nüfuz ettiği, ülkenin dört bir yandan işgal edildiği, iktidarların el değiştirdiği, kanunların işlevsiz hâle geldiği, şahısların ve zümrelerin çıkar mülahazasıyla hareket ettiği bir dönemde, ilkeli ve idealist hareket tarzıyla, göreve başladıktan kısa bir süre sonra yerel ve merkezî güçlerle karşı karşıya gelir. Resmî, gayriresmî hiçbir grubun, kliğin, partinin mensubu olmadığı için çok kolay gözden çıkarılır, görev yeri değiştirilir, istifaları kabul edilir. İari ve içtihadî meselelerden dolayı Il. Abdülhamid'in saltanat yıllarında statükocu yöneticilerle, 11. Meşrutiyet'ten sonra da ittihatçı kadrolarla anlaşamaz. Millî Mücadele yılları, bilhassa Diyarbakır Valiliği dönemi onun en zor geçen yıllarıdır. Pek çok idare adamı gibi o da ìstanbul hükümeti ile Millî Mücadeleciler arasında kalır. Mustafa Kemal ve Kâzım Karabekir'in Anadolu'daki faaliyetlerini ve Erzurum Kongresini ilk başta tereddütle karşılaması, "muhalif” olarak algılanmasına sebep olur. Mustafa Kemal ve arkadaşlarının bu algısı, bir ara değişiyor gibi olsa da Fâik Âli Bey'in kısa bir süre sonra Dâhiliye Nâzırlı̆̆ Müsteşarlığına getirilmesi yine "şüpheli" olarak görülmesine sebep olur. Cumhuriyet'in ilanından sonra değil mesleğinde yükselmek, aktif görevde bile bulunmamasının bu algıyla yakın bir ilgisi vardır. ${ }^{153}$ Nitekim Taha Toros da Fâik Âli'nin verimli bir çağda emekliye sevk olunmasını, zamanın politikasına boyun eğmemesine bağlar. ${ }^{154}$ Netice olarak, Fâik Âli'nin romantik, idealist,

\footnotetext{
${ }^{150}$ Fâik Âli, Midhat Paşa, ỉkinci Bin, Bursa 1324, $14 s$.

${ }^{151}$ Fâik Âli, Elhân-ı Vatan, ikinci Tab'ı, Matbaa-i Âmire, İstanbul, 1333-1917, $103 s$.

${ }^{152}$ Fâik Âli, Pâyitaht'n Kapısında (iki Perdelik Manzûm Temaşa), Ahmed ihsan ve Şürekâsı Matbaacılık Osmanlı Şirketi, İstanbul 1336-1918, 77 s.

${ }^{153}$ Kâmil Erdeha, age., s. 148. Yine bu algının tesiriyle Fâik Âli, 1931 yılında CHP'den değil, bağımsız olarak isstanbul milletvekilliğine aday olmuştur. "47 Müstakil Namzet", Cumhuriyet Gazetesi, 24 Nisan 1931, s. 1.

${ }^{154}$ Taha Toros, "Şair Fâik Âli'nin Son Günleri ve Hususiyetleri", Son Posta, 28.11.1950, s. 4.
} 
zarif $^{55}$ ve şair ruhlu kişiliğinin devlet adamlığına pek de olumlu katkı yapmadı̆̆ı söylenebilir.

KAYNAKÇA

“Aziz ve Kımetli Hatıralardan: Süleyman Nazif in Fâik Âli'ye Bir Mektubu”, Marmara, sayı: 1, Yıl: I, 15 Nisan 1936

AKYüZ, Kenan. Batı Tesirinde Türk Şiiri Antolojisi. ìstanbul: İnkılâp Kitabevi, 1995.

Ali Canip, Türk Edebiyatı Antolojisi, Devlet Matbaası, İstanbul 1934, s. 252.

ANDI, M. Fatih, "Fâik Âli Ozansoy'un Servet-i Fünûn Edebiyatı ve Tevfik Fikret'e Dair Midhat Cemal Kuntay'a Yazdığı Mektuplar”, Edebiyat Araştırmaları - 1. İstanbul: Kitabevi, 2000.

ATATÜRK, Kemal, Nutuk (Vesikalar), ìstanbul: Millî Eğitim Basımevi, 1982.

BEYSANOĞLU, Şevket, Diyarbakırlı Fikir ve Sanat Adamları, C 2. İstanbul: ışıl Matbaası, 1960.

BiRiNCi, Necat, Menemenlizâde Mehmed Tahir. Ankara: Kültür ve Turizm Bakanlığı Yayınları, 1988.

BOA, BEO (Dahiliye; MTV/80), 4405 / 330356.

BOA, BEO, $2523 / 189169$ (2. Belge)

BOA, BEO, 2560 / 191986.

BOA, BEO, 2804 / 210254.

BOA, BEO, 3402 / 255102.

BOA, BEO, 3590 / 269227.

BOA, BEO, 4162 / 312088.

BOA, BEO, 4227 / 316958.

BOA, BEO, 4332 / 324832.

BOA, BEO, 4459 / 334383.

BOA, BEO, 4529 / 339633.

BOA, DH.i.UM, 21/-1 / 72.

BOA, DH.i.uM, 21-1 / 72. (1. Ve 2. Belgeler)

BOA, DH.KMS, 53-1 / 71. (1/1. Ve 2. Belgeler)

BOA, DH.KMS, 53-1 / 91. (1/1., 2/1. Ve 3. Belgeler)

BOA, DH.KMS., 60/-1 / 39.

BOA, DH.MKT, 1043 / 21. (1. Belge)

BOA, DH.MKT, 2584 / 79.

BOA, DH.MKT, 917 / 90.

BOA, DH.MKT., 1208 / 45.

BOA, DH.MKT., 1213 / 85.

BOA, DH.MKT., 1274 / 18.

BOA, DH.MKT., 1274 / 74.

BOA, DH.MKT., $1297 / 41$.

BOA, DH.MKT., 2657 / 7.

BOA, DH.MKT., 2856 / 31.

BOA, DH.MKT., 2867 / 88.

BOA, DH.MKT., 2882 / 91.

BOA, DH.MKT., 732 / 24.

BOA, DH.MKT., 936 / 86.

${ }^{155}$ Nizamettin Nazif, Fâik Âli'nin vefatı münasebetiyle yazdığı yazıda onun "imparatorluğun en zarif mutasarrıf" olduğunu söyler. Nizamettin Nazif, "Allah Rahmet Eylesin”, Son Telgraf, 3 Ekim 1950. 
BOA, DH.MTV, 12 / 14. (1/1., 2., 4., 5., 9., 10., 11., 12., 19., 20., 22., 23., 24., 25., 26., 36. Belgeler) BOA, DH.MTV., 12 / 14.

BOA, DH.MTV., 331 / 31. (1., 2., 3., 4. Belgeler)

BOA, DH.MUi, 12-2 / 5.

BOA, DH.MUi., 12/-2 / 5 .

BOA, DH.SAID, Sıra No: 0112, sayfa: 413-414.

BOA, DH.SAIDd..., 112 / 413.

BOA, DH.ŞFR, $100 / 173$.

BOA, DH.ŞFR, 100 / 190.

BOA, DH.ŞFR, 602 / 79.

BOA, DH.ŞFR., $100 / 154$.

BOA, DH.ŞFR., 513 / 57.

BOA, DH.ŞFR., 62 / 37.

BOA, DH.UMUM, 112 / 46. (1. ve 3. Belgeler)

BOA, Fon Kodu: 30..11.1.0, Yer No: 56.17..8. Sayı: 5175.

BOA, i...DH.. $1469 / 93$.

BOA, i..DH.., 1496 / 1330/Za-47.

BOA, i..DH.., 1498 / 1331/Ca-01.

BOA, i..DH.., $1500 / 1331 / \mathrm{N}-17$.

BOA, i..DH.., 1501 / 1331/Za-22.

BOA, i..DuiT, $39 / 59$.

BOA, i..DuiT, $39 / 87$.

BOA, i..DuiT, $41 / 91$.

BOA, i..DuiT, 42 / 23.

BOA, i..DuiT, 42 / 94.

BOA, i.DH, 1433 / 21. (1. Belge)

BOA, i.DH., 1496 / 38. (1. Belge)

BOA, i.DH., 1497 / 20. (1. Belge)

BOA, i.DH., 1498 / 42. (2. Belge)

BOA, i.DH., 1499 / 35. (1. Belge)

BOA, i.DH., 1500 / 48. (2. Belge)

BOA, i.DH., 1501 / 49. (2. Belge)

BOA, i.DH., 1512 / 34. (2. Belge)

BOA, i.DuiT, 42 / 23.

BOA, i.Duit, 42 / 29.

BOA, MF.MKT, 565 / 4, (1., 2., 3. ve 4. Belgeler)

BOA, MV, $251 / 12$.

BOA, MV., 221 / 41.

BOA, ŞD, 39 / 34. (3., 5. ve 6. Belgeler)

BOA, ŞD. 39 / 34 .

BOA, Tasnif No: i.DH, 1433 / 21.

BOA, Y..A..RES., 151 / 48.

BOA, Y.A.RES, 151 / 48. (3. Belge)

ÇANKAYA, Mücellidoğlu Ali, Yeni Mülkiye Tarihi ve Mülkiyeliler (1860-1908 Atik Mekteb-i Fünûn-ı Mülkiyye - Mekteb-i Mülkiyye-i Şahane Mezunları) C Ill. Ankara: Mars Matbaası, 1968-1969.

ERDEHA, Kâmil, Millî Mücadelede Vilayetler ve Valiler. İstanbul Remzi Kitabevi, 1975.

Fâik Âli, “Fâik Âli Bey’in Bir Mektubu”. Tasvîr-i Efkâr, 7 Rebiyülâhir 1337 / 9 Kanunusani 1335 (1919), s. 1. 
Fâik Âli, Elhân-ı Vatan. İstanbul: ỉkinci Tab'ı, Matbaa-i Âmire, 1333-1917.

Fâik Âli, Midhat Paşa, ỉkinci Bin. Bursa 1324.

Fâik Âli, Pâyitaht'ın Kapısında (iki Perdelik Manzûm Temaşa). İstanbul: Ahmed ihsan ve Şürekâsı Matbaacılık Osmanlı Şirketi, 1336-1918,

FINDLEY, Carter V., (çev. Latif Boyacı-'̇zzet Akyol), Osmanlı Devletinde Bürokratik Reform Bâbuâli (1789-1922). İstanbul: İz Yayıncılık, 1994.

GÖNENSAY, Hıfzı Tevfik, Tanzimat'tan Zamanımıza Kadar Türk Edebiyatı Tarihi. ìstanbul: Remzi Kitabevi, 1949.

GÜR, Muhammet, Makale ve Mektuplarına Göre Süleyman Nazif. Marmara Üniversitesi Türkiyat Araştırmaları Enstitüsü, Basılmamış Doktora Tezi, İstanbul 1992.

HAYBER, Abdülkadir, Ebubekir Hâzım Tepeyran. Ankara: Kültür ve Turizm Bakanlı̆̆ı Yayınları, 1988.

HiSAR, Abdülhak Şinasi, "Fâik Âli (Ozansoy)”, Geçmiş Zaman Edipleri. İstanbul: Selis Kitaplar, 2005.

iNAL, ibnülemin Mahmud Kemal, "Faik Âli Bey”, Son Asır Türk Şairleri, Cüz: II. İstanbul: Millî Eğitim Basımevi, 1969.

ìsmail Habip, Edebî Yeniliğimiz (ikinci Kısım). ìstanbul: Devlet Matbaası, 1932.

KERiMî, Fatih, (Hazırlayan: Fazıl Gökçek). İstanbul Mektupları. İstanbul: Çağrı Yayınları, 2001.

KOÇ, Raşit, "Fâik Ali Ozansoy'un Şiirlerinin Tematik Olarak Incelenmesi”. Turkish Studies, 5/2, 2010.

KUNERALP, Sinan, Son Dönem Osmanlı Erkân ve Ricali (1839-1922),(Prosopografik Rehber). İstanbul: İsis Ltd. (1. Baskı 1999), 2. Baskı, 2003.

NADi, Yunus, Kurtuluş Savaşı Anıları. İstanbul: Çağdaş Yayınları, 1978.

NECATiGil, Behçet, Edebiyatımızda ìsimler Sözlüğü. ìstanbul: Varlık Yayınları, 7. Baskı, 1972.

Nizamettin Nazif, “Allah Rahmet Eylesin”, Son Telgraf. 3 Ekim 1950.

ÖRiK, Nahid Sırrı, "Haftada Bir: San'at Hayatından Akisler", Milliyet Gazetesi. 09.10.1950.

ÖZKIRIMLl, Atilla, Türk Edebiyatı Ansiklopedisi, C 2, Cem Yayınevi.

ÖZTUNA, Yılmaz, Avrupa Türkiyesini Kaybımız: Rumeli'nin Elden Çıkışı. İstanbul: Babıâli Kültür Yayıncılı̆̆ı, 2006.

PARLATIR, İsmail, “Faik Âli Ozansoy”, TDV isslam Ansiklopedisi, C 12, ístanbul, 1995.

S., Semih Mümtaz, “Evvel Zaman Içinde: Râbia Hatun Davası - Üstat Fâik Âli'nin Râbia Hatun'a ve Şiirlerine Dair Mühim Sözleri”. Akşam Gazetesi, 16 Ağustos 1948.

SADRETTiN, Mecdi, Sevdiklerimiz - 1, İstanbul: Milliyet Matbaası, 1929.

SEROPYAN, Sarkis, "Vicdanlı Bir Türk Valisi: Fâik Âli Ozansoy".İmparatorluğun Çöküş Döneminde Osmanlı Ermenileri Bilimsel Sorumluluk ve Demokrasi Sorunları: 23-25 Eylül 2005, İstanbul, İstanbul: Bilgi Üniversitesi Yayınları, 2011.

SEYFETTiNOĞLU, Muzaffer Budak, "Fâik Âli Ozansoy: Unutulan Şair". Sanat Dünyası, Nr: 216, 3, Aralık 1965.

SOYSüLlü, Mahmut, Süleyman Nazif Makaleleri (1909’a Kadar). Basılmamış Mezuniyet Tezi, İstanbul Üniversitesi, Edebiyat Fakültesi, Türkoloji Bölümü 1969-1970.

TANRIÖVER, Hamdullah Suphi, "Musahabe-i Edebiyye: Fâik Âli, Fâni Teselliler". Musavver Muhit, 22 Kanunusani 1324, C 1.

TOROS, Taha, “Şair Fâik Âli'nin Son Günleri ve Hususiyetleri”. Son Posta, 28.11.1950.

TOROS, Taha, Mâzî Cenneti. İstanbul: iletişim Yayınları, 1992.

URAZ, Murat, Edebiyat Antolojisi- 1 (Servet-i Fünun Zümresi Şairler, Romancılar). İstanbul: Semih Lütfi Erciyas Sühulet Kitabevi, 1938.

UYGUNER, Muzaffer, "Ölümünün Yirminci Yılında Fâik Âli Ozansoy". Mülkiyeliler Birliği Dergisi, C 3, 21. 